Article

\title{
A Tentative Study of the Effects of Heat-Inactivation of the Probiotic Strain Shewanella putrefaciens Pdp11 on Senegalese Sole (Solea senegalensis) Intestinal Microbiota and Immune Response
}

\author{
Marta Domínguez-Maqueda ${ }^{1, * \mathbb{D}}$, Isabel M. Cerezo ${ }^{1}$, Silvana Teresa Tapia-Paniagua ${ }^{1}$, Inés García De La Banda ${ }^{2}$, \\ Xabier Moreno-Ventas ${ }^{3} \mathbb{D}$, Miguel Ángel Moriñigo ${ }^{1}$ and Maria Carmen Balebona ${ }^{1}$ D \\ 1 Department of Microbiology, University of Málaga, 29010 Málaga, Spain; b22ceori@uma.es (I.M.C.); \\ stapia@uma.es (S.T.T.-P.); morinigo@uma.es (M.Á.M.); balebona@uma.es (M.C.B.) \\ 2 Spanish Institute of Oceanography, Oceanographic Center of Santander, 39080 Santander, Spain; \\ ines.gbanda@st.ieo.es \\ 3 Ecological Area of Water and Environmental Sciences and Technics, University of Cantabria, \\ 39005 Santander, Spain; morenox@unican.es \\ * Correspondence: martadm@uma.es
}

Citation: Domínguez-Maqueda, M.; Cerezo, I.M.; Tapia-Paniagua, S.T.; De La Banda, I.G.; Moreno-Ventas, X.; Moriñigo, M.Á.; Balebona, M.C. A Tentative Study of the Effects of Heat-Inactivation of the Probiotic Strain Shewanella putrefaciens Pdp11 on Senegalese Sole (Solea senegalensis) Intestinal Microbiota and Immune Response. Microorganisms 2021, 9, 808. https://doi.org/10.3390/ microorganisms 9040808

Academic Editor:

Gaspar Pérez-Martínez

Received: 3 February 2021

Accepted: 9 April 2021

Published: 12 April 2021

Publisher's Note: MDPI stays neutral with regard to jurisdictional claims in published maps and institutional affiliations.

Copyright: (c) 2021 by the authors. Licensee MDPI, Basel, Switzerland. This article is an open access article distributed under the terms and conditions of the Creative Commons Attribution (CC BY) license (https:// creativecommons.org/licenses/by/ $4.0 /)$.

\begin{abstract}
Concerns about safety, applicability and functionality associated with live probiotic cells have led to consideration of the use of non-viable microorganisms, known as paraprobiotics. The present study evaluated the effects of dietary administration of heat-inactivated cells of the probiotic strain Shewanella putrefaciens Pdp11 on the intestinal microbiota and immune gene transcription in Solea senegalensis. Results obtained were evaluated and compared to those described after feeding with viable Pdp11 cells. S. senegalensis specimens were fed with basal (control) diet or supplemented with live or heat inactivated $\left(60^{\circ} \mathrm{C}, 1 \mathrm{~h}\right.$ ) probiotics diets for 45 days. Growth improvement was observed in the group receiving live probiotics compared to the control group, but not after feeding with a probiotic heat-inactivated diet. Regarding immune gene transcription, no changes were observed for tnf $\alpha, i l-6, l y s-c 1, c 7, h s p 70$, and $h s p 90 a a$ in the intestinal samples based on the diet. On the contrary, $h s p 90 a b, g p 96, c d 4, c d 8, i l-1 \beta$, and $c 3$ transcription were modulated after probiotic supplementation, though no differences between viable and heat-inactivated probiotic supplemented diets were observed. Modulation of intestinal microbiota showed remarkable differences based on the viability of the probiotics. Thus, higher diversity in fish fed with live probiotic cells, jointly with increased Mycoplasmataceae and Spirochaetaceae to the detriment of Brevinemataceae, was detected. However, microbiota of fish receiving heat-inactivated probiotic cells showed decreased Mycoplasmataceae and increased Brevinemataceae and Vibrio genus abundance. In short, the results obtained indicate that the viable state of Pdp11 probiotic cells affects growth performance and modulation of S. senegalensis intestinal microbiota. On the contrary, minor changes were detected in the intestinal immune response, being similar for fish receiving both, viable and inactivated probiotic cell supplemented diets, when compared to the control diet.
\end{abstract}

Keywords: inactivated probiotics; Solea senegalensis; Shewanella putrefaciens Pdp11; immune response; microbiota

\section{Introduction}

Aquaculture is the fastest growing agro-industry sector in the world [1]. However, intensive aquaculture practices negatively affect the farmed fish physiology, disrupting the immune status and making fish prone to infectious diseases [2-4]. In order to contribute to aquaculture sustainability, practices to help fish maintain optimal gastrointestinal functionality are essential [5]. 
Fish gut mucosa is a very active immunological site and plays an essential role in host health, directly interacting with the aquatic environment [6,7]. Fish gut-associated lymphoid tissue (GALT) involves lymphocytes, plasmatic cells, granulocytes, and macrophages [8]. This mucosal surface supports large microbial populations, which play a key role in the intestinal environment and host-microbial interactions. Fish intestinal microbiome comprises complex communities with demonstrated impact on host health, mucosal development and cellular differentiation, metabolism, nutrition, and disease resistance [9].

Interestingly, the intestinal microbiota is strongly influenced by the rearing environment and seasonal or diet changes, which could lead to host immune-related pathologies $[8,10]$. Nowadays, modulation of the microbiota represents an interesting alternative for enhancing fish health status with probiotics receiving great attention as dietary supplements [11,12].

Probiotics are defined as live microbial cells that confer health benefits to the host [13-15] and factors such as viability may regulate their effects $[6,16]$. Shewanella putrefaciens Pdp11 is a Gram Negative bacteria isolated by our research group from the skin of Sparus aurata [17], and it has been demonstrated as a probiotic for farmed species such as S. aurata and S. senegalensis. Dietary administration of Pdp11 alive cells promotes the growth and improves the efficiency of feed utilization [18-20], stimulates S. senegalensis [17] and S. aurata [21] immune systems and intestinal functionality [18], increases resistance against bacterial pathogens such as Vibrio harveyi and Photobacterium damselae subsp. piscicida [19,22], and improves the stress tolerance of $S$. senegalensis specimens to high stocking density $[23,24]$. In addition, other studies have demonstrated the ability of Pdp11 to modulate the intestinal microbiota of larval and juvenile $S$. senegelensis specimens $[25,26]$ and to reduce the negative effects derived from the treatment with oxytetracycline, inducing the up-regulation of genes related to antiapoptotic effects and oxidative stress regulation [27].

Despite the wide range of benefits described for probiotics, concerns mainly related to safety, stability, and standardization have been raised with live probiotic cells [28]. Moreover, non-viable probiotic microorganisms have also shown ability to exert beneficial effects such as host immune stimulation [29,30] and modulation of the intestinal environment [31]. In this context, Tayernity and Guglielmetti (2011) [32] introduced the term "paraprobiotics" to name non-viable microbial cells or crude cell extracts that induce beneficial effects on the host. Heat-treatment is one of the most common methods for bacterial inactivation. In previous studies, heat inactivated Pdp11 probiotic cells showed immunostimulatory ability for $S$. aurata under in vitro and in vivo conditions [33,34]. However, as mentioned, this probiotic has demonstrated benefits for Senegalese sole when it is dietary incorporated as whole living cells, but its paraprobiotic effects have not yet been described in Senegalese sole. For this reason, the present tentative study contributes novel information on the potential use of Pdp11 as paraprobiotic in Senegalese sole. Though benefits derived from paraprobiotics have been described in homeotherm hosts [35,36], its application in aquaculture is still very limited.

Paraprobiotics have attractive advantages for industrial use. Besides the lack of potential virulence reversion, they entail decreased or no interaction with other components of the food products. Moreover, paraprobiotics supply greater food processing easiness, as they can be added before thermal processes, retaining their activity to the level required for the intended health benefits [35]. Moreover, in terms of simplicity, paraprobiotics could result in longer shelf life and greater convenience for storage and administration as well as supplements to immune-compromised individuals [37,38].

In order to evaluate the potential use of $\operatorname{Pdp} 11$ as a paraprobiotic in aquaculture, the effects of heat-inactivated Pdp11 cells on the intestinal microbiota, immune response, and oxidative stress were analyzed in S. senegalensis in comparison with effects exerted by live cells. 


\section{Materials and Methods}

\subsection{Ethics Approval}

All procedures involving fish were conducted in strict accordance with Guidelines established by the European Union (2010/63/UE) and the Spanish legislation (RD 1201/2005 and law 32/2007) for the use of laboratory animals. All experiments were approved by the Ethic Committee of Animal's Welfare of the Spanish Institute of Oceanography of Santander (CEBA-IEO).

\subsection{Probiotic Microorganism}

Shewanella putrefaciens Pdp11 was isolated from the skin mucus of healthy cultured gilthead seabream (Sparus aurata) and selected by its in vitro ability to inhibit the main pathogens of $S$. senegalensis [22]. Furthermore, this probiotic has increased resistance against bacterial infection in Senegalese sole $[17,19]$ and enhanced growth and improved intestinal integrity in sole juveniles [18,19]. Pdp11 cells were cultured following the methodology previously described by Tapia-Paniagua et al. (2014a) [23]. Briefly, Pdp11 was cultured on tryptic soy agar (Oxoid Ltd., Basingstoke, UK) added with $\mathrm{NaCl}(1.5 \%)$ (TSAs) at $22{ }^{\circ} \mathrm{C}$, $48 \mathrm{~h}$. After incubation, the bacterial growth on the surface of all the plates was scrapped, suspended in sterile phosphate-buffered saline (PBS) ( $\mathrm{pH} 7.4)$, and pooled. Then, cells were recovered by centrifugation $\left(6000 \times g, 15 \mathrm{~min}, 4{ }^{\circ} \mathrm{C}\right)$ and the pellet was suspended in PBS, adjusted to $10^{11}$ colony forming units $\mathrm{mL}^{-1}\left(\right.$ CFU mL $\left.{ }^{-1}\right)($ O.D.600 $\mathrm{nm}=1.5)$ and viable cell concentration determined by plate count on TSAs (Figure S1).

\subsection{Experimental Diets}

The commercial pellet diet Europa Elite LE-2 (Protein: 57\%; Fat: 18\%; Ash: 11.5\%; Cellulose. $0.2 \%$; P total: $1.7 \%$; Skretting, Burgos, Spain) was used as basal diet. To prepare experimental diets, $20 \mathrm{~mL}$ of the probiotic bacterial suspension previously described was divided into two aliquots. One of them was used as live cells while the other was incubated at $60{ }^{\circ} \mathrm{C}$ for $1 \mathrm{~h}$ for bacterial heat-inactivation. Finally, absence of bacterial growth was checked by inoculation of an aliquot of the heat-inactivated suspension on TSAs plates and incubation at $22{ }^{\circ} \mathrm{C}$ for $48 \mathrm{~h}$. Commercial feed was ground up, mixed with $10 \mathrm{~mL}$ of the probiotic suspension (live or dead cells; diets $\mathrm{P}$ and I, respectively) previously described, to obtain a dose equivalent to $10^{9} \mathrm{CFU} \mathrm{g}{ }^{-1}$ of feed. Control diet (diet C) was processed in the same manner and added with the same volume of PBS. Finally, diets were again made into pellets, allowed to dry and stored at $4{ }^{\circ} \mathrm{C}$ until use (Figure S1). Probiotic cell suspensions and diets were prepared and viability checked at the beginning of each week during the feeding trial.

\subsection{Experimental Design and Sample Collection}

Solea senegalensis specimens used in this study come from natural laying of the breeder stock kept in seawater 14,000 L tanks at the Spanish Oceanographic Institute in Santander (Spain). Once the spawn was collected and its appropriate hatching index verified, larvae were cultured in $150 \mathrm{~L}$ seawater tanks $\left(35.4 \mathrm{gL}^{-1}\right.$ salinity and $\left.19 \pm 0.50{ }^{\circ} \mathrm{C}\right)$ with a feeding based in rotifers, phytoplankton and Artemia enriched with Origreen (Skretting, Burgos, Spain). Weaning was carried out with Gemma microencapsulation feed (Skretting) and post larvae were transferred to $150 \mathrm{~L}$ seawater tanks $\left(35.4 \mathrm{gL}^{-1}\right.$ salinity and $\left.19 \pm 0.50{ }^{\circ} \mathrm{C}\right)$ and fed with commercial pellet Gemma (Skretting, Burgos, Spain). Then, fry were fed 8 times a day with the commercial Europa (Skretting, Burgos, Spain), not registering any mortality episode. Once they reached $10 \mathrm{~g}$ body weight, they were grown in $500 \mathrm{~L}$ seawater tanks $\left(35.4 \mathrm{gL}^{-1}\right.$ salinity and $\left.19 \pm 0.50{ }^{\circ} \mathrm{C}\right)$ at a stock density always below $7 \mathrm{~kg} \mathrm{~m}^{-2}$ and with a renovation rate of $300 \%$ day $^{-1}$. Feeding during fattening was carried out with Europa feed (Skretting, Burgos, Spain), which was maintained during the experiment. From this stock, 150 specimens were randomly sampled and distributed in six $150 \mathrm{~L}$ seawater tanks and acclimatized for two weeks prior to the experimental period keeping the same environmental, stock density and feeding conditions previously detailed. Specimens 
were acclimatized for 2 weeks prior to the experimental period. Health status of fish was visually checked based on the normal swimming and feeding behavior as well as coloration of skin and gills. Additionally, one fish per tank was euthanized by clove oil overdose (200 ppm) and dissected. The spleen, liver, and kidney were sampled and cultured on TSAs plates, a bacteriological medium widely used for the determination of most common bacterial pathogens for marine fish including Vibrio harveyi, Listonella anguillarum, Photobacteium damselae subsp. piscicida [17,22,39]. Inoculated plates were incubated at $22{ }^{\circ} \mathrm{C}$, up to 5 days and absence of bacterial growth was observed in all cases. After the acclimatization period, in which fish received commercial diet (diet $\mathrm{C}$ ), experimental diets (control diet supplemented with live, diet $\mathrm{P}$, and inactivated probiotic cells, diet I) were randomly assigned to duplicate groups. The initial fish weight was used to adjust the daily ration of feed according to the normal pattern in this species $\left(20 \mathrm{~g} \mathrm{~kg}^{-1}\right)$ and fish were fed 8 times a day for 45 days with the corresponding experimental diet. For growth parameter determinations, the specimens from each dietary treatment were weighed at $0,15,30$, and 45 days post feeding assay. For biometric determinations, all specimens were anaesthetized with clove oil (10-20 ppm).

Prior to sampling, 45 days after the feeding trial, fish were starved for $24 \mathrm{~h}$ to eliminate food remains, and six fish from each tank $(\mathrm{N}=12$ per diet) were sacrificed by an overdose of clove oil. Whole intestines were obtained after careful dissection under sterile conditions and fragments $(0.5 \mathrm{~cm})$ of the anterior (close to the stomach) and posterior (before the rectum) intestine stored at $-80^{\circ} \mathrm{C}$ for gene expression and intestinal microbiota analysis.

\subsection{RNA Isolation and Gene Expression Analysis}

Total RNA was isolated from anterior and posterior intestinal samples using GeneJET RNA Purification Kit (Thermo Scientific, Madrid, Spain) according to manufacturer's instructions. The purified RNA was suspended in DEPC-water (Sigma, St. Louis, MA, USA), quantified by using Qubit RNA BR assay kits (Thermo Scientific, Madrid, Spain) and quality checked by gel electrophoresis. DNase I treatment (Thermo Scientific, Madrid, Spain) was carried out to ensure complete DNA removal. Reverse transcription (RT) was performed using First Strand cDNA Synthesis Kit (Thermo Scientific, Madrid, Spain) with $1 \mu \mathrm{g}$ of total RNA and using oligo(dT)18 primers. The resulting cDNA was stored at $-20{ }^{\circ} \mathrm{C}$ until use.

Primers used to detect transcription of genes encoding two pro-inflammatory interleukins (il-1 $\beta$ and $i l-6)$, tumor necrosis factor alpha $(t n f-\alpha)$, complement components $(c 3$ and $c 7)$, lysozyme $C$ (lys-c1), cluster of differentiation 8 alpha and 4 ( $c d 8 \alpha$ and $c d 4)$, and heat shock proteins ( $g p 96, h s p 90 a a, h s p 90 a b$ and $h s p 70)$ are listed in Table 1 . In order to obtain accurate results, qPCR efficiency $\left(\left(E=\left(10^{[-1 / \text { slope }]}-1\right) \times 100\right)\right.$ with $0.95-1$ values was checked to ensure optimized and reproducible results.

Table 1. List of S. senegalensis genes analyzed in this study.

\begin{tabular}{|c|c|c|c|}
\hline Gene & Code & Sequence & Reference \\
\hline Beta actin 2 & $a c t b 2$ & $\begin{array}{l}\text { AATCGTGACCTCTGCTTCCCCCTGT (F) } \\
\text { TCTGGCACCCCATGTTACCCCATC (R) }\end{array}$ & [40] \\
\hline Ribosomal protein S4 & rps4 & $\begin{array}{l}\text { GTGAAGAAGCTCCTTGTCGGCACCA (F) } \\
\text { AGGGGGTCGGGGTAGCGGATG (R) }\end{array}$ & [40] \\
\hline Interleukin 1 beta & $i l-1 \beta$ & $\begin{array}{l}\text { CGCAGAAAGTGACATGTTGAGATTT (F) } \\
\text { GGAAGCGGGCAGACATGA (R) }\end{array}$ & [41] \\
\hline Interleukin 6 & $i l-6$ & $\begin{array}{l}\text { ACAATTTCCTGCAGAGATAAAAGTAAGCT (F) } \\
\text { CAAGCCCTCAGGCCTACAATATTAA }(\mathrm{R})\end{array}$ & {$[41]$} \\
\hline Complement C3 & $c 3$ & $\begin{array}{c}\text { ACCTTAGACTGCCCTACTCTGCTGTCCGTG (F) } \\
\text { GCACTGCACACATCATCCGTCTCAGAC (R) }\end{array}$ & [42] \\
\hline Complement C7 & $c 7$ & $\begin{array}{l}\text { GGCACACACTATCTGTCGCAGGGCTC (F) } \\
\text { GGCGAACGCCTGATGGTTTAACTCCAG (R) }\end{array}$ & [42] \\
\hline
\end{tabular}


Table 1. Cont.

\begin{tabular}{|c|c|c|c|}
\hline Gene & Code & Sequence & Reference \\
\hline C1 type lysozyme & lys-c1 & $\begin{array}{l}\text { CAGATCAACAGCCGCTATTGG (F) } \\
\text { GCTGATTCCACATGCATTTGAAGTG (R) }\end{array}$ & {$[41]$} \\
\hline Cluster of differentiation 4 & $c d 4$ & $\begin{array}{c}\text { GACCTCAGGCTGCAATGGT (F) } \\
\text { TGAGCAGAGTGATGGACAGACT (R) }\end{array}$ & [41] \\
\hline Cluster of differentiation 8 alpha & $c d 8 \alpha$ & $\begin{array}{l}\text { GTGCCAGCATTAAAAGCAACGA (F) } \\
\text { GCAGTCACAACTTCCGCTCTTT (R) }\end{array}$ & {$[41]$} \\
\hline Tumor necrosis factor alpha & $\operatorname{tnf} \alpha$ & $\begin{array}{l}\text { CTGGGACTGCTGGCACTTGGATTTG (F) } \\
\text { CAGTTCTCCACGCTGACGTACTGTCGAAC (R) }\end{array}$ & [43] \\
\hline Heat shock protein GP96 & gp96 & $\begin{array}{l}\text { GAGTCTTCTCCCTTTGTTGAGCGGCTG (F) } \\
\text { TGATGCCTTCCTTTGCCACGTTCTG (R) }\end{array}$ & {$[43]$} \\
\hline Heat shock protein 90AA & hsp90aa & $\begin{array}{l}\text { GACCAAGCCTATCTGGACCCGCAAC (F) } \\
\text { TTGACAGCCAGGTGGTCCTCCCAGT (R) }\end{array}$ & {$[44]$} \\
\hline Heat shock protein $90 \mathrm{AB}$ & hsp90ab & $\begin{array}{l}\text { TCAGTTTGGTGTGGGTTTCTACTCGGCTTA (F) } \\
\text { GCCAAGGGGCTCACCTGTGTCG (R) }\end{array}$ & {$[44]$} \\
\hline Heat shock protein 70 & hsp70 & $\begin{array}{l}\text { GCTATACCAGGGAGGGATGGAAGGAGGG (F) } \\
\text { CGACCTCCTCAATATTTGGGCCAGCA (R) }\end{array}$ & [43] \\
\hline
\end{tabular}

Reactions for each individual intestinal samples were carried out in $10 \mu \mathrm{L}$ final-volume consisting of $5 \mu \mathrm{L}$ SsoAdvanced SYBR Green Supermix (Bio-Rad Laboratories, Hercules, CA, USA), $0.5 \mu \mathrm{L}$ of each primer set $(10 \mu \mathrm{M}), 1 \mu \mathrm{L}$ template cDNA, and $3 \mu \mathrm{L}$ DEPC-water (Sigma). Quantitative PCR determinations were performed in triplicate in 96-well PCR plates and run in the CFX96 Touch Real-Time PCR Detection System (Bio-Rad Laboratories, Hercules, CA, USA). Amplification was followed by a standard melting curve from $65^{\circ} \mathrm{C}$ to $95^{\circ} \mathrm{C}$, in increments of $0.5^{\circ} \mathrm{C}$ for $5 \mathrm{~s}$ at each step, to verify the amplification of a single product. All individual intestinal samples were run in triplicate and in parallel with two reference genes, $\beta$-actin (actb2) and ribosomal proteins $\mathrm{S4}$ ( $r p s 4$ ) [40]. To assess the stability of reference genes the Genorm algorithm was used [45]. Relative mRNA expression was calculated using the comparative Cq method $2^{(-\Delta \Delta \mathrm{Cq})}$ [46].

\subsection{DNA Extraction and Microbiota Characterization}

Intestines from six specimens from each tank $(\mathrm{N}=12$ per diet) were collected and cut longitudinally on a sterile petri dish, differentiating anterior and posterior sections. In order to characterize diet effects on the intestinal microbiota, intestinal lumen contents were pooled and stored at $-80^{\circ} \mathrm{C}$ until DNA extraction. In this way, variation between individual fish can be represented as a whole since pooled intestinal content samples were obtained from individuals fed with the same diet. This practice was carried out in order to avoid bias, as has been proposed in previous studies [47-49] Total DNA from each pool was obtained as described by Martínez et al. (1998) [50]. The dried DNA pellet was resuspended in $100 \mu \mathrm{L}$ of DECP water (Sigma). DNA was re-precipitated with sodium acetate and washed with ethanol. Finally, DNA was centrifuged $(12,000 \times g, 5 \mathrm{~min})$ and the pellet dried and resuspended in $100 \mu \mathrm{L}$ DECP water (Sigma). Agarose gel $(1.5 \%, w / v)$ electrophoresis was used with RedSafe Nucleic Acid Staining Solution 20.000X (InTRON Biotechnology, Seoul, Korea) to visually check DNA integrity. Suitable samples of each treatment were mixed and DNA quantity determined using Qubit DNA BR assay kits and the Qubit 2.0 (Thermo Scientific). Bacterial 16S rRNA V3-V4 regions were sequenced using the Illumina MiSeq Platform (Chunlab, Inc., Seoul, South Korea) with primers 341F CCTACGGGNGGCWGCAG and 805R GACTACHVGGGTATCTAATCC (ChunLab). All Illumina reads were analyzed with FastaQC software in order to assess sequence quality. Further data processing including trimming and 16S rRNA analysis and visualization were performed with pipeline based on the MOTHUR software package (1.39.5 version). Briefly, chimeras were removed by 
using UCHIME version 4.2 (http:/ / www.drive5.com/usearch/manual/uchime_algo.html (accessed on 15 January 2021), effective Tags obtained) and sequences were aligned against EzBiocloud database [2018 may] and clustered into operational taxonomic units (OTUs) with $97 \%$ identity cutoff and a threshold set at $0.005 \%$ [51].

\subsection{Growth Performance Calculations}

The survival rate (SR), weight gain rate (WGR) and specific growth rate (SGR) were used to evaluate the fish survival and growth performance, respectively. Parameters were calculated as follows.

$$
\begin{gathered}
\operatorname{SR}(\%)=100 \times \mathrm{Nf} / \mathrm{Ni} \\
\operatorname{WGR}(\%)=100 \times(\mathrm{Wf}-\mathrm{Wi}) / \mathrm{Wi} \\
\operatorname{SGR}(\% / \mathrm{d})=100 \times(\ln \mathrm{Wf}-\ln \mathrm{Wi}) / \mathrm{d}
\end{gathered}
$$

Nf: final fish number; Ni: initial fish number; Wf: final individual weight; Wi: initial individual weight; $d$ : length of feeding trial (days).

\subsection{Statistical Analysis}

Statistical analyses were conducted using IBM SPSS Statistics 22.0. Normality and homogeneity of variance of the data was determined by using Shapiro-Wilk and Levene's test, respectively. Differences were statistically analyzed by one-way analysis of variance (ANOVA) with Tukey and Games-Howell post hoc tests when statistical requirements were fulfilled. Non-normally distributed data were analyzed by the non-parametric Kruskal-Wallis test, followed by a multiple comparison test. Statistical significance was set for $p \leq 0.05$.

\section{Results}

\subsection{Growth Performance}

Tanks were checked three times a day for the presence of non-consumed feed at the bottom. Fish showed similar behavior towards the diets regardless of the presence or ab-sence of the probiotics and no learning period was implemented. No mortality was observed during the feeding trial, with $100 \%$ SR in all fish groups (Table 2). Fish fed with diet $P$ exhibited significant increased rates $(p<0.05)$ in the final body weight, WGR and SGR compared to those receiving control (diet $C$ ) and heat-inactivated probiotic (diet I) diets. On the contrary, no differences were observed in growth performance parameters between diet $\mathrm{C}$ and diet I (Table 2).

Table 2. Growth performance of $S$. senegalensis fed three different diets over 45 days. The three diets were: control diet (Diet C), the same diet supplemented with alive probiotic cells (Diet $P$ ), and inactivated probiotic cells (Diet I).

\begin{tabular}{cccc}
\hline & Diet C & Diet P & Diet I \\
\hline Initial body weight (g) & $28.52 \pm 1.42^{\mathrm{a}}$ & $30.18 \pm 1.37^{\mathrm{a}}$ & $30.87 \pm 1.37^{\mathrm{a}}$ \\
Final body weight $(\mathrm{g})$ & $34.86 \pm 2.44^{\mathrm{a}}$ & $46.40 \pm 2.18^{\mathrm{b}}$ & $37.10 \pm 2.18^{\mathrm{a}}$ \\
SR (\%) & $100.00 \pm 0.00^{\mathrm{a}}$ & $100.00 \pm 0.00^{\mathrm{a}}$ & $100.00 \pm 0.00^{\mathrm{a}}$ \\
WGR (\%) & $22.23 \pm 3.35^{\mathrm{a}}$ & $48.81 \pm 4.12^{\mathrm{b}}$ & $20.18 \pm 3.01^{\mathrm{a}}$ \\
SGR (\%/d) & $0.45 \pm 0.02^{\mathrm{a}}$ & $0.88 \pm 0.05^{\mathrm{b}}$ & $0.41 \pm 0.02^{\mathrm{a}}$ \\
\hline
\end{tabular}

Values are means \pm standard deviations of three replicate groups. Mean values with the different superscripts in the same row are significantly different $(p<0.05)$. SR: survival rate; WGR: weight gain rate; SGR: specific growth rate.

\subsection{Gene Expression Analysis}

No differences in relative transcription of genes involved in cellular stress hsp90aa and $h s p 70$ were observed in fish receiving diets supplemented with Pdp11 probiotic cells, whether live or inactivated, compared to fish fed with the control diet. However, after 
feeding with diets formulated with the probiotics, significant gp96 and hsp90ab downregulation was observed in posterior and both intestinal sections, respectively, of fish receiving diet $\mathrm{P}$ and diet $\mathrm{I}$, compared to the control diet group (Figure 1A,B).

A

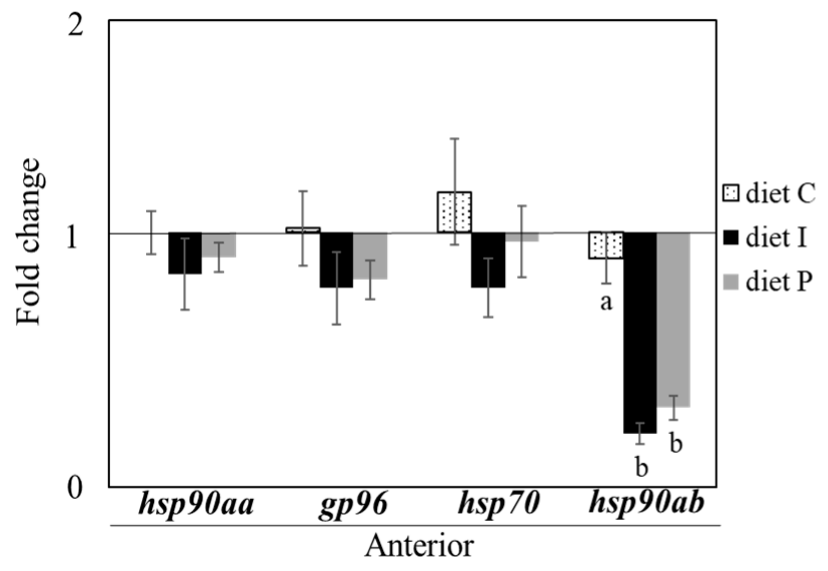

B

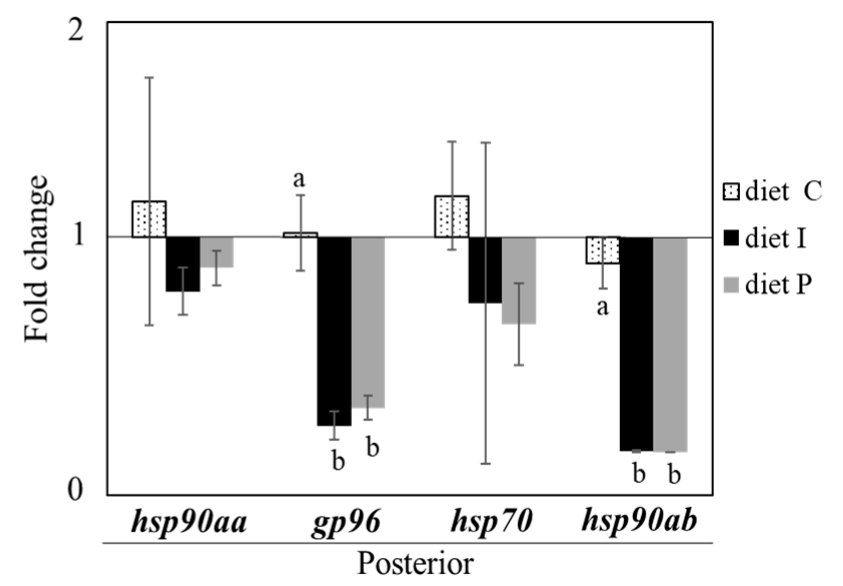

Figure 1. Relative transcription (normalized with $a c t b 2$ and $r p s 4$ ) of genes involved in cellular stress in anterior (A) and posterior (B) intestinal sections of S. senegalensis fed with live (diet P) and inactivated (diet I) Pdp11 cells. Four genes including $h s p 90 a a, g p 96, h s p 70$ and $h s p 90 a b$ were analyzed by RT-qPCR. Data (mean \pm standard deviation) are presented as relative fold change of target genes in fish fed with supplemented diets compared to control group (diet C). Different letters indicate significant differences between diets determined by one-way ANOVA test $(p \leq 0.05)$.

Genes related to the inflammatory response including tnf- $\alpha$, il- 6 and $i l-1 \beta$, did not show significant differences in anterior intestinal sections based on the diet used. In addition, no differences were observed in the posterior intestinal sections except for il$1 \beta$, which resulted significantly up-regulated in fish fed with diet $\mathrm{P}$ compared to the control group (Figure 2A,B). On the contrary, both probiotic diets induced significant $c d 4$, and $c d 8 \alpha$ increased transcription in anterior intestinal sections, whereas significant $c d 4$ down regulation was observed in the posterior intestine. Transcription of $c d 8 \alpha$ gene was also significantly down-regulated in posterior intestinal sections of fish fed with diet I (Figure 2).

A

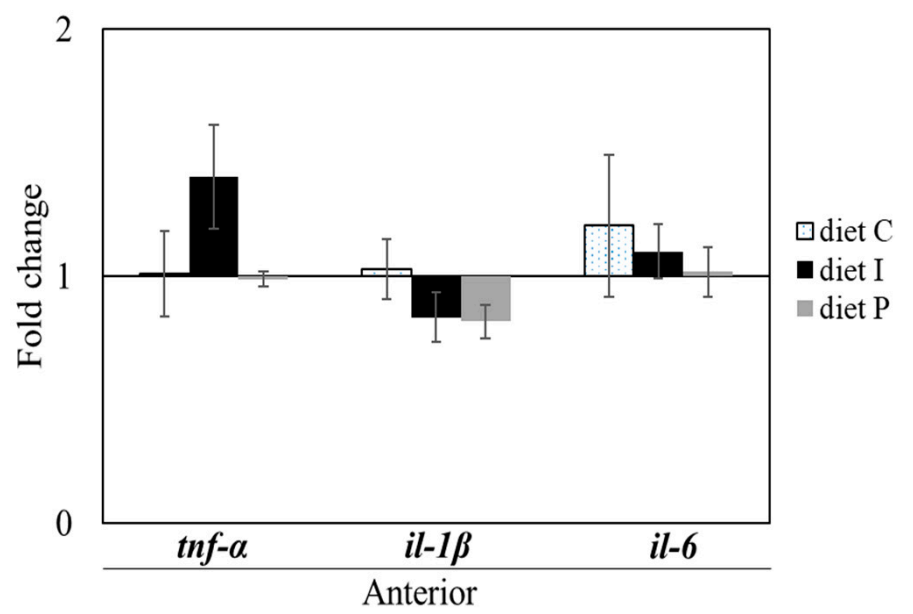

B

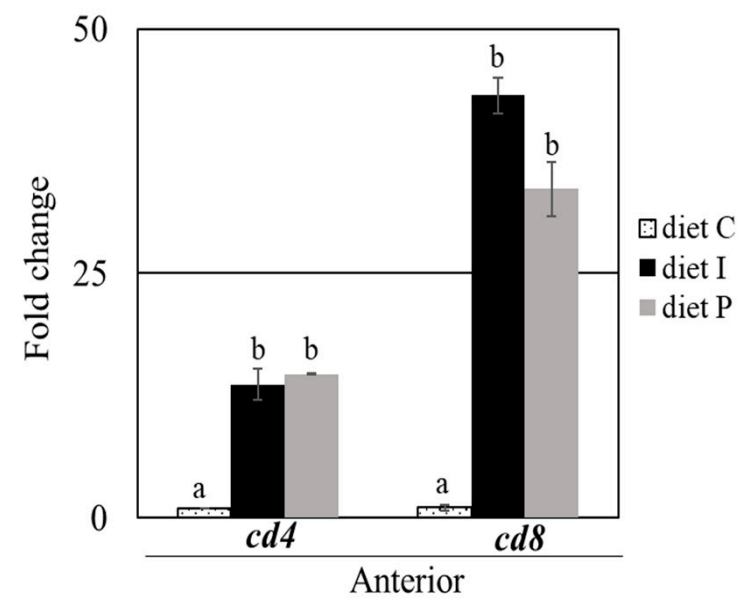

Figure 2. Cont. 
C

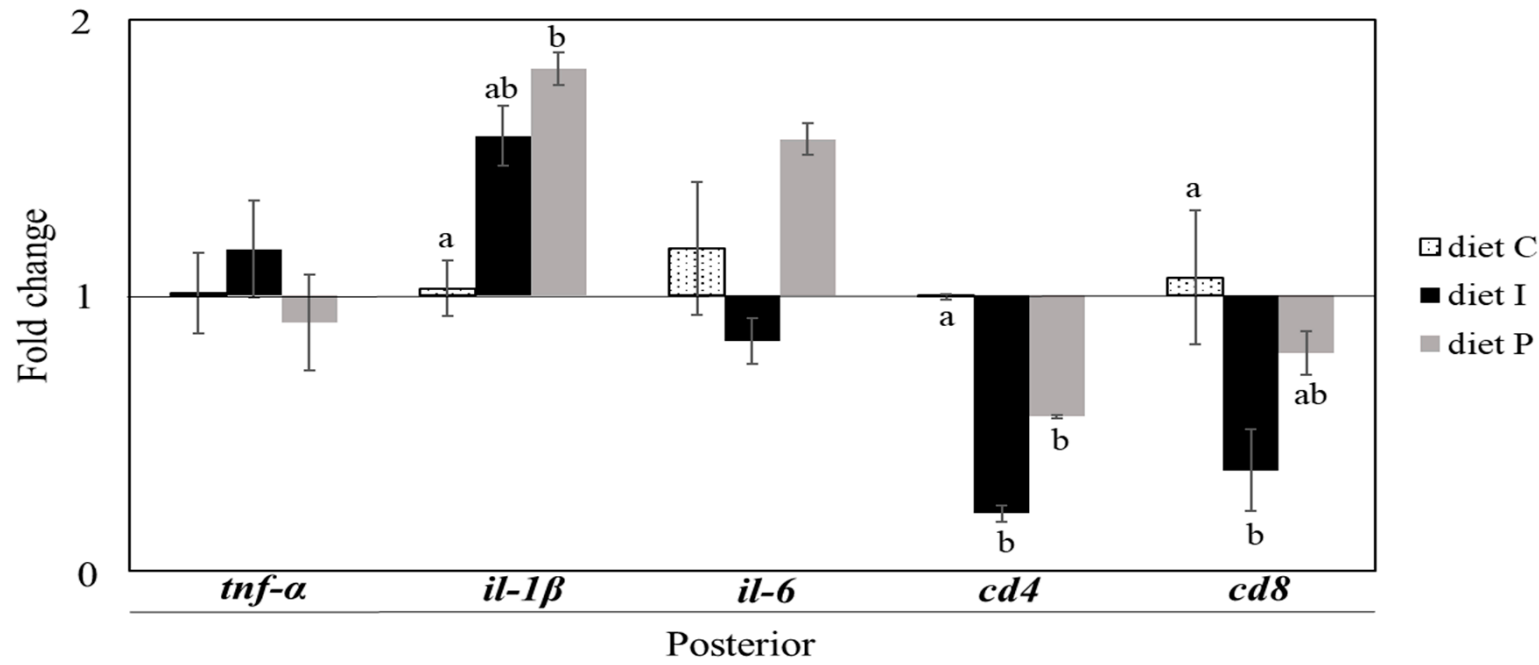

Figure 2. Relative gene transcription (normalized with $a c t b 2$ and $r p s 4$ ) of genes involved in pro-inflammatory and immune response in anterior $(\mathbf{A}, \mathbf{B})$ and posterior $(\mathbf{C})$ intestinal sections of $S$. senegalensis fed with live (diet $P$ ) and inactivated (diet I) Pdp11 cells. Five genes including $t n f-\alpha, i l-1 \beta, i l-6, c d 8 \alpha$, and $c d 4$ were analysed by RT-qPCR. Data (mean \pm standard deviation) are presented as relative fold change of target genes in fish fed with supplemented diets compared to control group (diet C). Different letters indicate significant differences between diets determined by one-way ANOVA test $(p \leq 0.05)$.

When genes involved in the humoral immune response $(c 3, c 7$ and $l y s-c 1)$ were analyzed, changes associated with the diet were only detected in $c 3$ transcription. Thus, statistically significant $c 3$ down-regulation was observed in anterior and posterior intestinal sections of fish fed with inactivated probiotic cells, whereas significant changes were only observed in posterior sections of fish fed with diet P. On the other hand, no changes in $c 7$ and $l y s-c 1$ relative gene expression were observed after probiotic diet supplementation (Figure 3A,B).

A

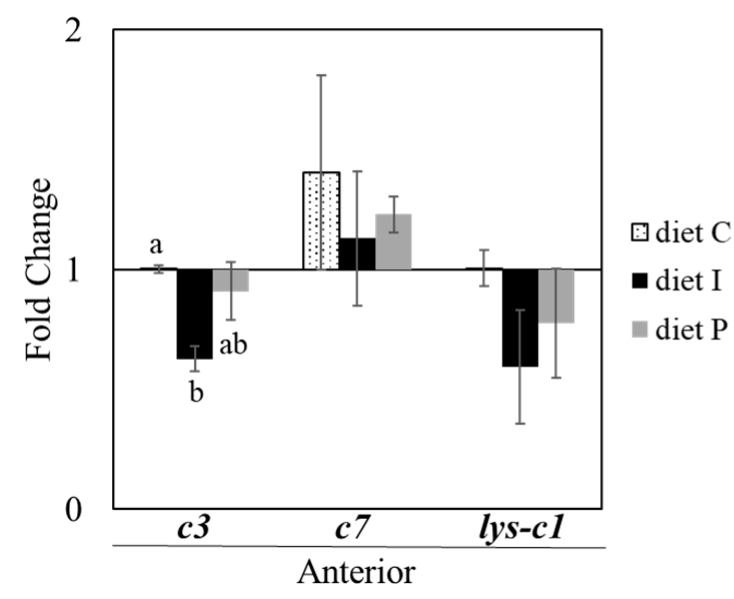

B

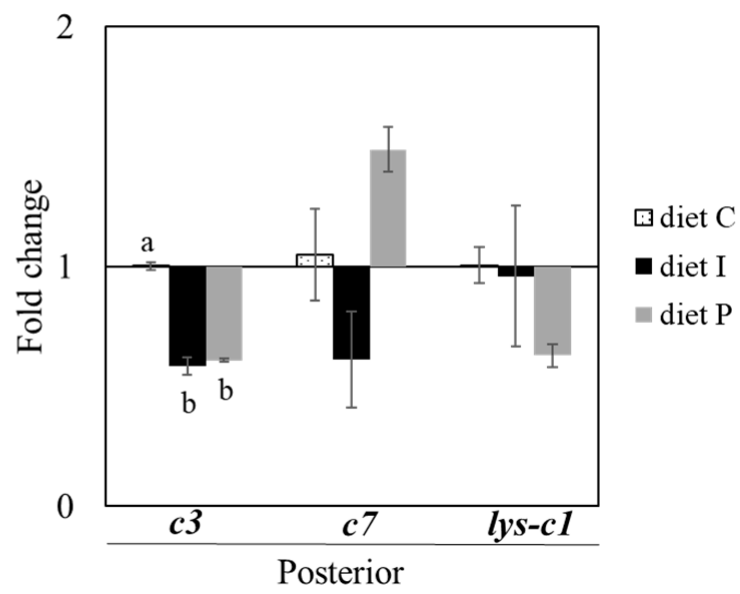

Figure 3. Relative gene transcription (normalized with $a c t b 2$ and $r p s 4$ ) of genes involved in complement components and lysozyme in anterior (A) and posterior (B) intestinal sections of $S$. senegalensis fed with alive (diet $\mathrm{P}$ ) and inactivated (diet I) cells of Pdp11. Three genes including $c 7, c 3$, and $l y s-c 1$ were analysed by RT-qPCR. Data (mean \pm standard deviation) are presented as relative fold change of target genes in fish fed with supplemented diets compared to control group (diet $C$ ). Different letters indicate significant differences between diets determined by one-way ANOVA test $(p \leq 0.05)$. 


\subsection{Analysis of the Intestinal Microbiota}

After sequencing, a total of 333,384 raw reads were obtained for both forward and reverse directions. The mean read depth per sample was 55,564 $\pm 26,101.58$ (mean $\pm \mathrm{SD}$ ). After removing non-specific amplicons, amplicons not assigned to the target taxon and chimeras, 48,330.33 $\pm 24,467.21$ (mean $\pm S D$ ) sequences were retained. Filtering based on rarefaction curves was carried out and a total of 20,723 reads per sample was obtained. Singletons and doubletons were removed and 2628 OTUs at $97 \%$ gene similarity cutoff against EzBioCloud database were used for subsequent analysis. Sequence libraries displayed Good's coverage estimations close to $100 \%$ (97.04 \pm 1.07$)$, suggesting that the sequences identified represent most of the bacterial composition present in each sample.

Since the effects of pooling intestinal samples rely on how representative such inoculum is regarding the intestinal ecosystem, the abundance and the variety of bacterial species can be observed as a whole in any case. In this way, results obtained showed differences in the microbiota composition between fish fed with different diets (Figures 4-6). Microbiota taxonomic analysis showed three dominant phyla shared by all the samples: Proteobacteria, Tenericutes, and Spirochaetes (Figure 4). After inclusion of live Pdp11 cells in the diet, increased relative abundance percentages of phyla such as Bacteroidetes, Proteobacteria, and Firmicutes and a reduction of the phylum Tenericutes were observed compared to fish receiving control diet (Figure 4A). On the other hand, fish fed with diet I showed increased Spirochaetes and decreased Tenericutes relative abundance compared to fish fed with control diet (Figure 4A). When considering microbiota composition in the posterior intestinal sections, decreased relative abundance of Spirochaetes in favor of Tenericutes was observed in fish receiving diet $\mathrm{P}$, whilst the opposite was detected when diet I was administered (Figure 4B).

A

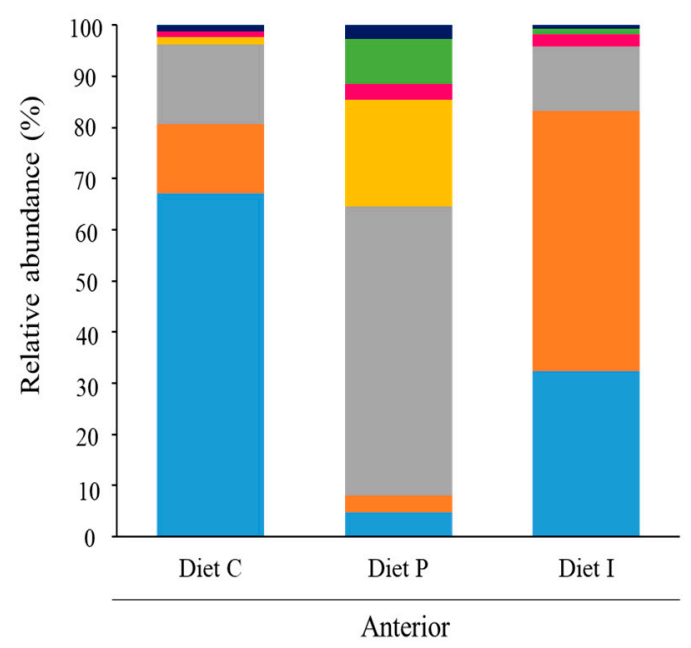

B

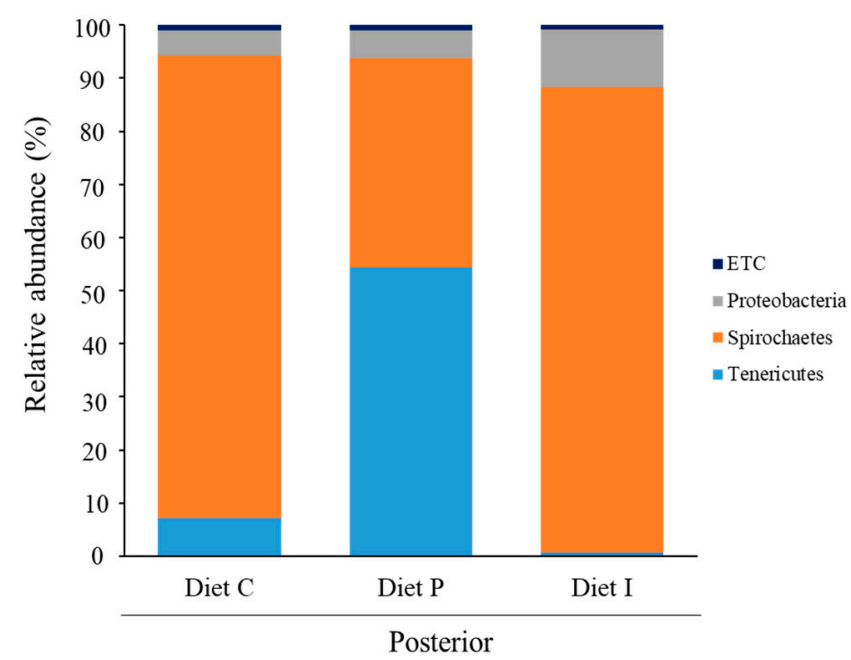

Figure 4. Microbiota composition (relative operational taxonomic units (OTUs) composition) at phylum level of pooled intestinal contents from anterior (A) and posterior (B) intestinal sections of $S$. senegalensis specimens fed with control diet (diet C) and diet supplemented with live (diet P) or inactivated (diet I) Pdp11 cells. ETC indicates relative abundance percentage below $1 \%$.

When microbiota composition was analyzed at family level, the microbiota of the anterior intestinal sections of $S$. senegalensis specimens fed with diet $P$ contained a total of 19 families with relative abundance percentages $>1 \%$, and a clear dominance of Pseudomonadaceae and Xanthomonadaceae (Figure 5A). On the contrary, microbiota of fish fed with diets $\mathrm{C}$ and I were similar in family composition, though increased Brevinemataceae and decreased Mycoplasmataceae percentages were observed in fish fed with inactivated probiotic cells (Figure 5A). In addition, Vibrionaceae family was only detected in the microbiota of $S$. senegalensis specimens fed with diet I. The microbiota of posterior intestinal sections 
showed lower family numbers in fish fed all the diets (Figure 5B). In the case of diet $\mathrm{P}$, Mycoplasmataceae_f1 was the most abundant family ( $54.33 \%)$, followed by Spirochaetaceae $(25.78 \%)$, whilst Brevinemataceae was more abundant in fish receiving $\operatorname{diet} \mathrm{C}$ and diet $\mathrm{I}$. Furthermore, Vibrionaceae relative percentage was higher (10.6\%) in the microbiota of fish receiving diet I. On the contrary, Spirochaetaceae was detected in the microbiota of posterior intestinal sections of fish fed control diet and diet P. Table S1 shows relative abundance percentages at family level.

A

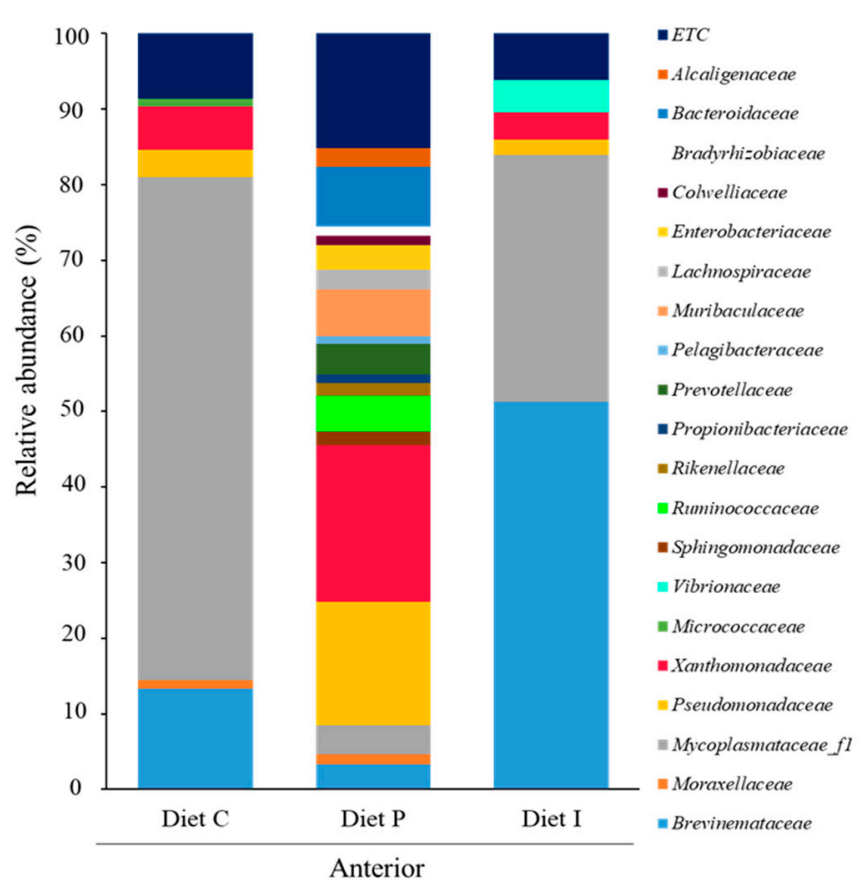

B

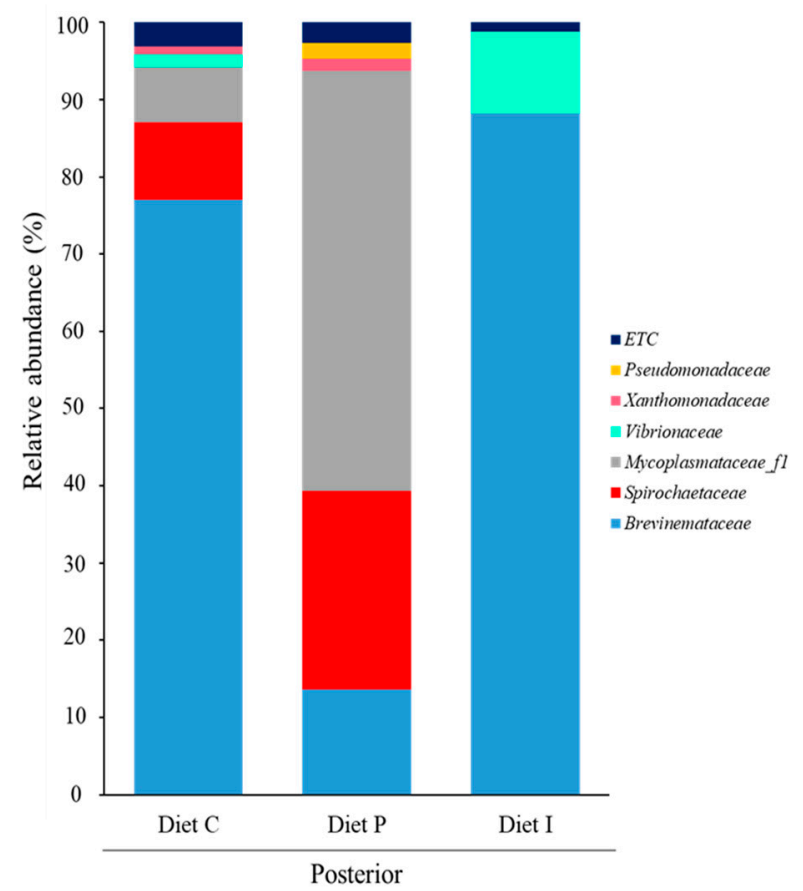

Figure 5. Microbiota composition (relative OTUs composition) at family level of pooled intestinal contents from anterior (A) and posterior (B) intestinal sections of S. senegalensis specimens fed with control diet (diet C) and diets supplemented with live (diet P) or inactivated (diet I) Pdp11 cells. ETC indicates relative abundance percentage below 1\%.

Dominant genera comprising the microbiota in all samples (diet $\mathrm{P}$, diet I and control groups) are represented in Figure 6 (relative abundance percentages $>1 \%$ ). Administration of diet $P$ noticeably increased the number of genera and phylotypes in anterior intestinal sections, with Pseudomonas, Bacteroides, and Stenotrophomonas genera to the head (Figure 6A). On the contrary, this variety decreased in posterior intestinal sections, with only four genera (Brevinema, Mycoplasma_g12, Pseudomonas and Stenotrophomonas) and two phylotypes (Mycoplasmataceae_f1 and AF166259_g (Spirochaetaceae)) showing relative abundance percentages above 1\% (Figure 6B). Among them, Brevinema genus and AF166259_g phylotype represented about $80 \%$ of the total abundance (Figure $6 \mathrm{~B}$ ). The dietary inclusion of inactivated probiotic cells resulted in increased abundance of genera such as Vibrio and especially Brevinema, in both anterior and posterior intestinal regions, with very high dominance in the latter, where these genera represented almost $88 \%$ of the total sequences (Figure $6 \mathrm{~A}, \mathrm{~B}$ ). A remarkable absence of Mycoplasma_g12 genus was observed in the posterior sections of fish fed the inactivated cells (diet I) compared to microbiota of fish receiving $\operatorname{diet} C$ and diet P (Figure 6B). Overall, a total of 231 and 263 genera were identified in the anterior and posterior intestinal sections, respectively (Figure S2). Of these, 27 and 36 genera were shared by the microbiota of anterior and posterior intestinal sections, respectively, regardless of the diet received by the fish (Figure S2). Microbiota of specimens fed with the diet supplemented with live probiotic cells showed higher number of unique genera (71 and 85 in anterior and posterior intestinal sections, respectively) compared to fish fed 
with control or inactivated probiotic diet. This latter, showed higher abundance of unique genera in anterior intestinal sections (60) compared to fish fed control diet (34) (Figure S2).

A

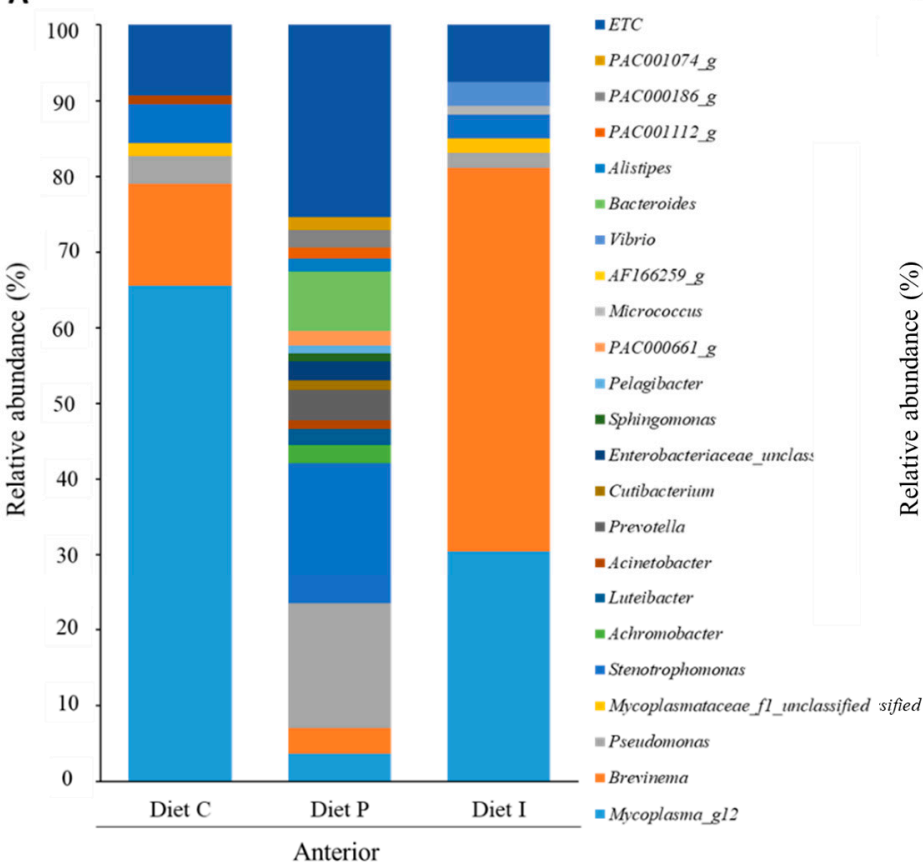

B

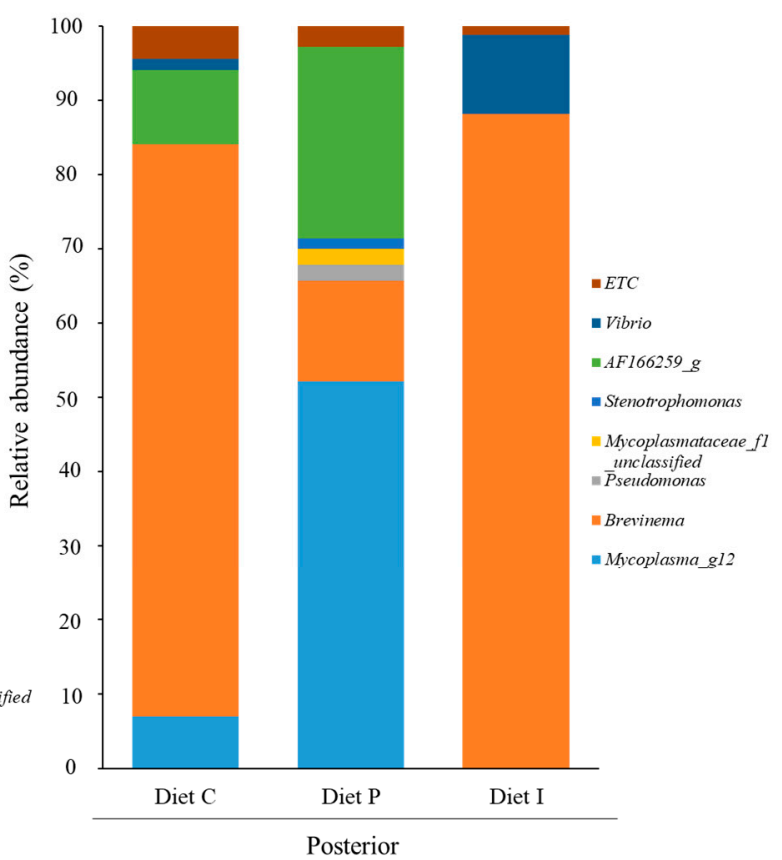

Figure 6. Microbiota composition (relative OTUs composition) at genus level of pooled intestinal contents from anterior (A) and posterior (B) intestinal sections of S. senegalensis specimens fed with control diet (diet C) and diets supplemented with live (diet P) or inactivated (diet I) Pdp11 cells. ETC indicates relative abundance percentage below 1\%.

\section{Discussion}

The improvements in growth performance in fish fed with some heat-killed probiotics such as Lactobacillus plantarum strain L-137 in Oreochromis niloticus [52] or Bacillus sp. SJ-10 in Paralichthys olivaceus [53] compared to basal diets have been reported. In the case of the probiotics S. putrefaciens Pdp11, benefits associated to the administration of viable cells are well documented in S. aurata and S. senegalensis [24,27,54,55]. However, advantages in terms of safety and product stability derived from the use of non-viable cells make the investigation of the effects of inactivated cells worthwhile. Results obtained in the present work indicate that dietary administration of heat-inactivated Pdp11 cells to S. senegalensis does not result in similar growth performance improvement compared to that observed with live cells, though no decreased growth was detected compared to the control diet.

Several authors have reported that probiotics supplemented in the fish diet can effectively modulate the intestinal microbiota, with associated improved growth, immunity, and disease resistance [56]. In agreement with results previously reported by TapiaPaniagua et al., 2010 [24], Spirochaetes and Proteobacteria were predominant phyla in the intestine of $S$. senegelansis specimens. Interestingly, Tenericutes considerably increased in the anterior sections of fish fed diet $C$ and I, but, except for fish receiving probiotic live cells, it was practically absent in the posterior sections (Figure 4). In this context, Bano et al. (2007) [57], suggest that different Mycoplasma ribotypes may dominate in anterior and posterior intestine, suggesting partitioning by location in the digestive tract of the fish Gillichthys mirabilis. This could explain differences in the bacterial taxa abundances in both intestinal sections detected in this study, which could be related to enzymatic activities or slightly to $\mathrm{pH}$ values along the gut tract of $S$. senegalensis [58].

On the other hand, in this study, the highest bacterial diversity was observed in the microbiota of fish fed with the diet P. Bacteroidetes are represented by a series of philotypes belonging to Muribaculaceae family (PAC000186_g, PAC001074_g and PAC001112_g) and 
Ruminococcaceae family (PAC000661_g). Both, Bacteroidetes and Firmicutes are associated with better amino acid, carbohydrate, and lipid metabolism in Penaeus monodon [59]. However, Bacteroidaceae family is one of the predominant taxa in anterior intestinal sections of fish fed the diet P. In this sense, Bacteroides genus has been reported as member of the intestinal microbiota of freshwater and marine fish [60-62] with the ability to transform the primary bile acids [63] in essential metabolic regulators for lipid metabolism [64]. In this context, previous studies $[19,25,26]$, have shown significant differences in the fatty acid profiles and the presence of lipid inclusions in the liver of $S$. senegalensis fed with a diet supplemented with Pdp11 compared to specimens receiving a control diet. These findings point out to a better metabolic activity for fish fed the diet $\mathrm{P}$.

The analysis at genus level in anterior and posterior intestinal samples showed the predominance of genus Brevinema, especially in fish fed control and inactivated diets. This genus has also been previously reported as predominant in S. senegalensis intestinal tract $[25,26]$. High abundance of the phylum Spirochaetes has also been observed in carnivorous fish microbiota, including mahi-mahi (Coryphaena hippurus) and great barracuda (Sphyraena barracuda) [65]. In addition, Corrigan et al. (2015) [66] found that Spirochaetes, jointly with Firmicutes, could play an important role in the fermentation of dietary carbohydrates, transporting non-digestible sugars across fish cellular membranes. Normally, there is a divergence in the capacity to utilize dietary carbohydrates between carnivorous species, which cannot be satisfactory due to anomalies in glucose metabolism [67]. In this sense, the great abundance of Spirochaetes and therefore of the genus Brevinema, mostly induced by the probiotic inactivated cells, could be related to promoting a better ability to deal with glucose in a fish species, that, despite its carnivorous feeding habits, seems to have high requirements in this term [68].

Furthermore, a common phylum in marine fish is Proteobacteria [69], standing out for participating in various biogeochemical processes (carbon, nitrogen, and sulfur cycling) in aquatic ecosystems [70]. Here, this phylum is present in the intestinal microbiota of fish receiving all diets and is mostly represented by genera including Pseudomonas, Stenotrophomonas, Luteibacter, and Vibrio. It should be noted that, unlike in fish receiving inactivated probiotic cells, Vibrio suffers a reduction in fish fed with the P diet, resulting in agreement with previous studies [27]. Bacterial diseases occur easily when the immunity of fish declined, or the diet and environment changed. In any case, in our study, Vibrio seems not to play a pathogenic role according to the absence of fish mortality and disease symptoms as well as in the gene expression results obtained.

Gastrointestinal microbes play a critical role in the development and maturation of GALT, which in turn mediate a variety of host immune functions [71]. As a consequence, diets modulating the intestinal microbiota, may play important roles in mediating immunity [72]. In this work, the immunomodulatory effect on $S$. senegalensis caused by dietary probiotic administration was studied. Immunomodulation by intestinal microbiota is attributed to the effects on the release of cytokines, including interleukins, tumor necrosis factors, among others, which regulate both innate and adaptive immune response. Heat shock proteins (HSPs) play a key role in the cell stress response system, preventing protein aggregation, promoting protein homeostasis and it can be up-regulated in cells exposed to different abiotic and biotic factors [44,73,74]. Two important isoforms (hsp90aa and hsp90ab) proteins have been found to exert protective effects against heat or cold shock, hyperosmotic stress, immune response, and heavy metal toxicity and have essential roles in the folding and translocation of proteins [75]. Protein encoded by $g p 96$ is also involved in the immune response, including maturation of antigen presenting cells and stimulation of pro-inflammatory cytokines [76]. Notable increased transcription in gp96 gene expression, and associated pro-inflammatory response, has been reported in S. senegalensis specimens infected with P. damselae subsp. piscicida [77]. Similarly, Saprolegnia parasitica uptake process by host cells is guided by a gp96-like receptor [78]. On the other hand, stimulation of $h s p 70$ and $h s p 90$ gene expression is also considered as a marker to assess stress [79]. In this context, similar relative $h s p 70, h s p 90$ expression in fish fed with both experimental diets ( $\mathrm{P}$ 
and I), jointly with gp96 and hsp90ab down-regulation, could indicate that S. senegalensis specimens fed with the probiotic diets were not under a situation involving cellular stress in the intestinal environment.

Additionally, increased expression of pro-inflammatory genes is indicative of an immunologically activated status [80]. In fish, the involvement of $i l-6$ in the promotion of antibody production has been reported in Nile tilapia (Oreochromis niloticus) [80] and Japanese pufferfish (Fugu rubripes) [81]. Furthermore, in agreement with previous studies, the supplementation of live and heat-inactivated probiotic feed additives increased the expression of pro-inflammatory genes, including $i l-1 \beta$ and $t n f-\alpha$, normally enhancing the phagocytic activities of leukocytes [82-84]. Similarly, feeding with Pdp11 live or dead cells has resulted in increased $i l-1 \beta$ in the posterior intestinal sections. Considering the fact that pro-inflammatory cytokines may boost immune response, but prolonged and excessive expression might result in negative effects, results observed could suggest an immune support in fish, especially when live cells are administered.

On the other hand, complement components play an important role in non-specific and specific immunity [85]. In fish, the complement system is the major component of the innate immune response, and plays an essential role in microbial killing, phagocytosis, inflammatory reactions, immune complex clearance, and antibody production [86]. Several studies demonstrated that probiotics such as Pediococcus acidilactici, Lactobacillus rhamnosus, Enterococcus faecium, and Lactobacillus plantarum modulate $c 3$ and $c 4$ gene expression associated with protection against bacterial pathogens in fish [87]. In this way, probiotic administration could improve complement component levels in fish when facing infectious stress. In this way, increased complement gene expression was not observed in the present study and a general and similar down-regulation of complement genes was detected regardless of the probiotic diet administered. Normally, components of the complement system increase their synthesis immediately upon inflammatory stimuli and improve fish immunity [85]. However, a tight regulation of inflammatory processes is necessary to avoid adverse effects of immune activation, especially in the absence of the pathogen [88]. Similarly, lysozyme (lys-c1) is a conserved antimicrobial protein critical in host defense against pathogens [89], and like the majority of gene expression levels observed, could indicate that individuals are not under stress.

Several studies documented improved immune response after incorporation of probiotics and paraprobiotics in fish diets as results of the interaction between bacterial and intestinal cells [90]. However, this interaction can occasionally result in dysbiosis. This is a basic type of cellular stress and a common reason for hsp induction [91,92]. Genes such as $g p 96$ and $h s p 90 a b$, have been involved in the acute phase response and the immune regulation against microbial pathogens [93-95]. Dysbiosis has also been associated with increased transcription of pro-inflammatory cytokines [96,97]. In our study, changes of the intestinal microbiota observed in fish fed the diets $\mathrm{P}$ and I were neither associated to significant increased transcription of genes encoding key proteins in the stress response nor pro-inflammatory cytokines, suggesting that dysbiosis was not induced. Furthermore, this phenomenon is also associated to T cell imbalance and inflammation [98]. In our study, fish receiving the diets supplemented with viable or inactivated probiotic cells showed significant increases of $c d 4$ and $c d 8 \alpha$ genes in the anterior intestinal sections. The direct killing activity by an apparent MHC-independent mechanism against both facultative intracellular and extracellular bacteria demonstrated by CD4 and CD8 $\alpha$ cells has been reported [99], and it could explain the up-regulation detected in this study without inflammatory response. In this way, this up-regulation does not imply killing activity to occur in all cases because it is dependent on the effector and target levels [99], and it could be in agreement with the absence of inflammatory and oxidative stress response observed in our study. 


\section{Conclusions}

In this work, the effects of heat-inactivated cells of the probiotic strain Pdp11 on the intestinal microbiota and immune response were evaluated in $S$. senegalensis. Results obtained show that the probiotic dietary inclusion of live or inactivated cells modulate the microbiota and expression of genes involved in the intestinal immune response of S. senegalensis. Similar relative gene transcription levels were obtained in fish fed both diets, showing that bacterial viability is not essential for the immunomodulatory effect observed in S. senegalensis. On the contrary, remarkable differential modulation of the intestinal microbiota, with higher variety of bacterial taxa, was observed when fish received live probiotic cells. Notwithstanding, further research including controlled intervention studies with challenge assays will contribute to improving the information on the potential effects of diets during infection with pathogenic microorganisms. In addition, mechanistic studies will allow the dilucidation of the mechanisms involved in the different response to the diets and ascertain other potential benefits on S. senegalensis.

Supplementary Materials: The following are available online at https:/ / www.mdpi.com/article/1 0.3390/microorganisms9040808/s1, Figure S1: Graphical representation of the Section 2.2 (Probiotic microorganisms) and Section 2.3 (Experimental diets). Figure S2: Venn diagrams demonstrating the distribution of genera shared in the anterior (A) and posterior (B) intestinal sections of $S$. senegalensis specimens fed control diet (diet C) and the same supplemented with live (diet P) or inactivated (diet I) cells of the probiotic. Genera numbers are generated from subsets of each group. Table S1: Relative microbial abundances at family level of the anterior and posterior intestinal sections of $S$. senegalensis specimens fed control diet (diet C) and the same supplemented with alive (diet $P$ ) or inactivated (diet I) cells of the probiotics Pdp11. Blanks indicate relative abundance percentage below $1 \%$.

Author Contributions: M.D.-M.: Investigation/Methodology/Data curation/Writing. I.M.C. Ortega: Formal analysis/Software/Writing. S.T.T.-P.: Conceptualization/Methodology/Writing. I.G.D.L.B.: Data curation/Software. X.M.-V.: Data curation/Software. M.Á.M.: Visualization/Supervision/ Validation. M.C.B.: Visualization/Supervision/Validation. All authors have read and agreed to the published version of the manuscript.

Funding: This study was supported by MINECO (grant no. AGL2014-51839-C5-2-R and AGL201783370-C3-3-R) and FEDER funds.

Institutional Review Board Statement: The study was conducted according to the guidelines of the Declaration of Helsinki, and approved by the Ethics Committee of the European Union (2010/63/UE) and the Spanish legislation (RD 1201/2005 and law 32/2007) for the use of laboratory animals. All experiments were approved by the Ethic Committee of Animal's Welfare of the Spanish Institute of Oceanography of Santander (CEBA-IEO).

Informed Consent Statement: Not applicable.

Data Availability Statement: Molecular sequence data reported in this paper were deposited in the National Center for Biotechnology Information (NCBI) Sequence Read Archive (SRA accession: PRJNA694873).

Conflicts of Interest: The authors declare no conflict of interest. The funders had no role in the design of the study; in the collection, analyses, or interpretation of data; in the writing of the manuscript, or in the decision to publish the results.

\section{References}

1. Food and Agriculture Organization of the United Nations (FAO). World Aquaculture 2015: A Brief Overview; FAO: Rome, Italy, 2017.

2. Wedemeyer, G. Physiology of Fish in Intensive Culture Systems; Springer Science \& Business Media (SSBM): Berlin, Germany, 1996.

3. Bowden, T.J. Modulation of the immune system of fish by their environment. Fish Shellfish Immunol. 2008, 25, 373-383. [CrossRef]

4. Plumb, J.A. Health Maintenance of Cultured Fishes: Principal Microbial Diseases; CRC Press: Boca Raton, FL, USA, 2018.

5. Ringø, E.; Hoseinifar, S.H.; Ghosh, K.; Doan, H.V.; Beck, B.R.; Song, S.K. Lactic acid bacteria in finfish-An update. Front. Microbiol. 2018, 9, 1818. [CrossRef] [PubMed]

6. Lazado, C.C.; Caipang, C.M.A. Mucosal immunity and probiotics in fish. Fish Shellfish Immunol. 2014, 39, 78-89. [CrossRef] [PubMed] 
7. Salinas, I.; Zhang, Y.A.; Sunyer, J.O. Mucosal immunoglobulins and B cells of teleost fish. Dev. Comp. Immunol. 2011, 35, $1346-1365$. [CrossRef]

8. Rombout, J.H.; Abelli, L.; Picchietti, S.; Scapigliati, G.; Kiron, V. Teleost intestinal immunology. Fish Shellfish Immunol. 2011, 31, 616-626. [CrossRef] [PubMed]

9. Llewellyn, M.; Boutin, S.; Hoseinifar, S.H.; Derome, N. Teleost microbiomes: Progress towards their characterization, manipulation and applications in aquaculture and fisheries. Front. Microbiol. 2014, 5, 207. [CrossRef]

10. Standen, B.T.; Rodiles, A.; Peggs, D.L.; Davies, S.J.; Santos, G.A.; Merrifield, D.L. Modulation of the intestinal microbiota and morphology of tilapia, Oreochromis niloticus, following the application of a multi-species probiotic. Appl. Microbiol. Biotechnol. 2015, 99, 8403-8417. [CrossRef]

11. Caipang, C.M.A.; Lazado, C.C. Nutritional impacts on fish mucosa: Immunostimulants, pre- and probiotics. Mucosal Health Aquac. 2015, 211-272. [CrossRef]

12. Sayes, C.; Leyton, Y.; Riquelme, C. Probiotic Bacteria as an Healthy Alternative for Fish Aquaculture. Antibiotics Use in Animals; Savic, S., Ed.; InTech Publishers: Rijeka, Croatia, 2018; pp. 115-132. [CrossRef]

13. Merrifield, D.L.; Dimitroglou, A.; Foey, A.; Davies, S.J.; Baker, R.T.M.; Bøgwald, J.; Castex, M.; Ringø, E. The current status and future focus of probiotic and prebiotic applications for salmonids. Aquaculture 2010, 302, 1-18. [CrossRef]

14. Nayak, S.K. Probiotics and immunity: A fish perspective. Fish Shellfish Immunol. 2010, 29, 2-14. [CrossRef]

15. Pérez-Sánchez, T.; Balcázar, J.L.; Merrifield, D.L.; Carnevali, O.; Gioacchini, G.; de Blas, I.; Ruiz-Zarzuela, I. Expression of immune-related genes in rainbow trout (Oncorhynchus mykiss) induced by probiotic bacteria during Lactococcus garvieae infection. Fish Shellfish Immunol. 2011, 31, 196-201. [CrossRef] [PubMed]

16. Muñoz-Atienza, E.; Araújo, C.; Lluch, N.; Hernández, P.E.; Herranz, C.; Cintas, L.M.; Magadán, S. Different impact of heatinactivated and viable lactic acid bacteria of aquatic origin on turbot (Scophthalmus maximus L.) head-kidney leucocytes. Fish Shellfish Immunol. 2015, 44, 214-223. [CrossRef] [PubMed]

17. Díaz-Rosales, P.; Arijo, S.; Chabrillón, M.; Alarcón, F.J.; Tapia-Paniagua, S.T.; Martínez-Manzanares, E.; Balebona, M.C.; Moriñigo, M.A. Effects of two closely related probiotics on respiratory burst activity of Senegalese sole (Solea senegalensis, Kaup) phagocytes, and protection against Photobacterium damselae subsp. Piscicida. Aquaculture 2009, 293, 16-21. [CrossRef]

18. Sáenz de Rodrigáñez, M.A.; Díaz-Rosales, P.; Chabrillón, M.; Smidt, H.; Arijo, S.; León-Rubio, J.M.; Alarcón, F.J.; Balebona, M.C.; Moriñigo, M.A.; Cara, J.B.; et al. Effect of dietary administration of probiotics on growth and intestine functionality of juvenile Senegalese sole (Solea senegalensis, Kaup 1858). Aquac. Nutr. 2009, 15, 177-185. [CrossRef]

19. De La Banda, I.G.; Lobo, C.; León-Rubio, J.M.; Tapia-Paniagua, S.T.; Balebona, M.C.; Moriñigo, M.A.; Moreno-Ventas, X.; Lucas, M.L.; Linares, F.; Arce, F.; et al. Influence of two closely related probiotics on juvenile Senegalese sole (Solea senegalensis, Kaup 1858) performance and protection against Photobacterium damselae subsp. piscicida. Aquaculture 2010, 306, 281-288. [CrossRef]

20. Lobo, C.; Tapia-Paniagua, S.T.; Moreno-Ventas, X.; Alarcón, F.J.; Rodríguez, C.; Balebona, M.C.; Moriñigo, M.A.; García de la Banda, I. Benefits of probiotic administration on growth and performance along metamorphosis and weaning of Senegalese sole (Solea senegalensis). Aquaculture 2014, 433, 183-195. [CrossRef]

21. Cordero, H.; Guardiola, F.A.; Tapia-Paniagua, S.T.; Cuesta, A.; Meseguer, J.; Balebona, M.C.; Moriñigo, M.A.; Esteban, M.A. Modulation of immunity and gut microbiota after dietary administration of alginate encapsulated Shewanella putrefaciens Pdp11 to gilthead seabream (Sparus aurata L.). Fish Shellfish Immunol. 2015, 45, 608-618. [CrossRef]

22. Chabrillón, M.; Rico, R.M.; Balebona, M.C.; Moriñigo, M.A. Adhesion to sole, Solea senegalensis Kaup, mucus of microorganisms isolated from farmed fish, and their interaction with Photobacterium damselae subsp. piscicida. J. Fish Dis. 2005, 28, 229-237. [CrossRef]

23. Tapia-Paniagua, S.T.; Vidal, S.; Lobo, C.; Prieto-Alamo, M.J.; Jurado, J.; Cordero, H.; Cerezuela, R.; de la Banda, I.G.; Esteban, M.A.; Balebona, M.C.; et al. The treatment with the probiotic Shewanella putrefaciens Pdp11 of specimens of Solea senegalensis exposed to high stocking densities to enhance their resistance to disease. Fish Shellfish Immunol. 2014, 41, 209-221. [CrossRef]

24. Tapia-Paniagua, S.T.; Chabrillón, M.; Díaz-Rosales, P.; de la Banda, I.G.; Lobo, C.; Balebona, M.C.; Morinigo, M.A. Intestinal microbiota diversity of the flat fish Solea senegalensis (Kaup, 1858) following probiotic administration. Microb. Ecol. 2010, 60, 310-319. [CrossRef]

25. Tapia-Paniagua, S.T.; Lobo, C.; Moreno-Ventas, X.; de la Banda, I.G.; Moriñigo, M.A.; Balebona, M.C. Probiotic supplementation influences the diversity of the intestinal microbiota during early stages of farmed Senegalese sole (Solea senegalensis, Kaup 1858). Mar. Biotechnol. 2014, 16, 716-728. [CrossRef]

26. Tapia-Paniagua, S.T.; Díaz-Rosales, P.; García de la Banda, I.; Lobo, C.; Clavijo, E.; Balebona, M.C.; Moriñigo, M.A. Modulation of certain liver fatty acids in Solea senegalensis is influenced by the dietary administration of probiotic microorganisms. Aquaculture 2014, 424, 234-238. [CrossRef]

27. Tapia-Paniagua, S.T.; Vidal, S.; Lobo, C.; de la Banda, I.G.; Esteban, M.A.; Balebona, M.C.; Moriñigo, M.A. Dietary administration of the probiotic SpPdp11: Effects on the intestinal microbiota and immune-related gene expression of farmed Solea senegalensis treated with oxytetracycline. Fish Shellfish Immunol. 2015, 46, 449-458. [CrossRef]

28. Choudhury, T.G.; Kamilya, D. Paraprobiotics: An aquaculture perspective. Rev. Aquac. 2019, 11, 1258-1270. [CrossRef]

29. Panigrahi, A.; Kiron, V.; Satoh, S.; Watanabe, T. Probiotic bacteria Lactobacillus rhamnosus influences the blood profile in rainbow trout, Oncorhynchus mykiss (Walbaum). Fish Physiol. Biochem. 2010, 36, 969-977. [CrossRef] [PubMed] 
30. Dawood, M.A.O.; Koshio, S.; Ishikawa, M.; Yokoyama, S. Immune responses and stress resistance in red sea bream, Pagrus major, after oral administration of heat-killed Lactobacillus plantarum and vitamin C. Fish Shellfish Immunol. 2016, 54, 266-275. [CrossRef]

31. Sawada, D.; Sugawara, T.; Ishida, Y.; Aihara, K.; Aoki, Y.; Takehara, I.; Takano, K.; Fujiwara, S. Effect of continuous ingestion of a beverage prepared with Lactobacillus gasseri CP2305 inactivated by heat treatment on the regulation of intestinal function. Food Res. Int. 2016, 79, 33-39. [CrossRef]

32. Tavernity, V.; Guglielmetti, S. The immunomodulatory properties of probiotic microorganisms beyond their viability (ghost probiotics: Proposal of paraprobiotic concept). Genes Nutr. 2011, 6, 261-274. [CrossRef] [PubMed]

33. Díaz-Rosales, P.; Salinas, I.; Rodríguez, A.; Cuesta, A.; Chabrillón, M.; Balebona, M.C.; Moriñigo, M.A.; Esteban, M.A.; Meseguer, J. Gilthead seabream (Sparus aurata L.) innate immune response after dietary administration of heat-inactivated potential probiotics. Fish Shellfish Immunol. 2006, 20, 482-492. [CrossRef] [PubMed]

34. Salinas, I.; Díaz-Rosales, P.; Cuesta, A.; Meseguer, J.; Chabrillón, M.; Moriñigo, M.A.; Esteban, M.A. Effect of heat-inactivated fish and non-fish derived probiotics on the innate immune parameters of a teleost fish (Sparus aurata L.). Vet. Immunol. Immunopathol 2006, 111, 279-286. [CrossRef] [PubMed]

35. De Almada, C.N.; Almada, C.N.; Martinez, R.C.; Sant'Ana, A.S. Paraprobiotics: Evidences on their ability to modify biological responses, inactivation methods and perspectives on their application in foods. Trends Food Sci. Technol. 2016, 58, 96-114. [CrossRef]

36. Andresen, V.; Gschossmann, J.; Layer, P. Heat-inactivated Bifidobacterium bifidum MIMBb75 (SYN-HI-001) in the treatment of irritable bowel syndrome: A multicentre, randomised, double-blind, placebo-controlled clinical trial. Lancet Gastroenterol. Hepatol. 2020, 5, 658-666. [CrossRef]

37. Chuang, L.; Wu, K.G.; Pai, C.; Hsieh, P.S.; Tsai, J.J.; Yen, J.H.; Lin, M.Y. Heat-killed cells of lactobacilli skew the immune response toward T helper 1 polarization in mouse splenocytes and dendritic cell-treated T cells. J. Agric. Food Chem. 2007, 55, 11080-11086. [CrossRef]

38. Ishikawa, H.; Kutsukake, E.; Fukui, T.; Sato, I.; Shirai, T.; Kurihara, T.; Maeda, Y. Oral administration of heat-killed Lactobacillus plantarum strain b240 protected mice against Salmonella enterica Serovar Typhimurium. Biosci. Biotechnol. Biochem. 2010, 74, 1338-1342. [CrossRef]

39. Chabrillón, M.; Arijo, S.; Díaz-Rosales, P.; Balebona, M.C.; Moriñigo, M.A. Interference of Listonella anguillarum with potential probiotic microorganisms isolated from farmed gilthead seabream (Sparus aurata, L.). Aquac. Res. 2006, 37, 78-86. [CrossRef]

40. Infante, C.; Matsuoka, M.P.; Asensio, E.; Cañavate, J.P.; Reith, M.; Manchado, M. Selection of housekeeping genes for gene expression studies in larvae from flatfish using real-time PCR. BMC Mol. Biol. 2008, 9, 28. [CrossRef] [PubMed]

41. Montero, D.; Benitez-Dorta, V.; Caballero, M.J.; Ponce, M.; Torrecillas, S.; Izquierdo, M.; Zamorano, M.J.; Manchado, M. Dietary vegetable oils: Effects on the expression of immune-related genes in Senegalese sole (Solea senegalensis) intestine. Fish Shellfish Immunol. 2015, 44, 100-108. [CrossRef] [PubMed]

42. Prieto-Álamo, M.J.; Abril, N.; Osuna-Jiménez, I.; Pueyo, C. Solea senegalensis genes responding to lipopolysaccharide and copper sulphate challenges: Large-scale identification by suppression subtractive hybridization and absolute quantification of transcriptional profiles by real-time RT-PCR. Aquat. Toxicol. 2009, 91, 312-319. [CrossRef] [PubMed]

43. Osuna-Jiménez, I.; Williams, T.D.; Prieto-Álamo, M.J.; Abril, N.; Chipman, J.K.; Pueyo, C. Immune-and stress-related transcriptomic responses of Solea senegalensis stimulated with lipopolysaccharide and copper sulphate using heterologous cDNA microarrays. Fish Shellfish Immunol. 2009, 26, 699-706. [CrossRef] [PubMed]

44. Manchado, M.; Salas-Leiton, E.; Infante, C.; Ponce, M.; Asensio, E.; Crespo, A.; Zuasti, E.; Cañavate, J.P. Molecular characterization, gene expression and transcriptional regulation of cytosolic HSP90 genes in the flatfish Senegalese sole (Solea senegalensis Kaup). Gene 2008, 416, 77-84. [CrossRef]

45. Vandesompele, J.; De Preter, K.; Pattyn, F.; Poppe, B.; Van Roy, N.; De Paepe, A.; Speleman, F. Accurate normalization of real-time quantitative RT-PCR data by geometric averaging of multiple internal control genes. Genome Biol. 2002, 3, 1-12. [CrossRef] [PubMed]

46. Schmittgen, T.D.; Livak, K.J. Analyzing real-time PCR data by the comparative C T method. Nat. Protoc. 2008, 3, 1101. [CrossRef] [PubMed]

47. Wu, S.; Gao, T.; Zheng, Y.; Wang, W.; Cheng, Y.; Wang, G. Microbial diversity of intestinal contents and mucus in yellow catfish (Pelteobagrus fulvidraco). Aquaculture 2010, 303, 1-7. [CrossRef]

48. Hao, K.; Wu, Z.Q.; Li, D.L.; Yu, X.B.; Wang, G.X.; Ling, F. Effects of dietary administration of Shewanella xiamenensis A-1, Aeromonas veronii A-7, and Bacillus subtilis, single or combined, on the grass carp (Ctenopharyngodon idella) intestinal microbiota. Probiotics Antimicrob. Proteins 2017, 9, 386-396. [CrossRef]

49. Tapia-Paniagua, S.T.; Balebona, M.D.C.; Firmino, J.P.; Rodríguez, C.; Polo, J.; Moriñigo, M.A.; Gisbert, E. The effect of spray-dried porcine plasma on gilthead seabream (Sparus aurata) intestinal microbiota. Aquac. Nutr. 2020, 26, 801-811. [CrossRef]

50. Martínez, G.; Shaw, E.M.; Carrillo, M.; Zanuy, S. Protein salting-out method applied to genomic DNA isolation from fish whole blood. BioTechniques 1998, 24, 238-239. [CrossRef]

51. Bokulich, N.A.; Subramanian, S.; Faith, J.J.; Gevers, D.; Gordon, J.I.; Knight, R.; Caporaso, J.G. Quality-filtering vastly improves diversity estimates from Illumina amplicon sequencing. Nat. Methods 2013, 10, 57-59. [CrossRef] 
52. Van Nguyen, N.; Onoda, S.; Van Khanh, T.; Hai, P.D.; Trung, N.T.; Hoang, L.; Koshio, S. Evaluation of dietary Heat-killed Lactobacillus plantarum strain L-137 supplementation on growth performance, immunity and stress resistance of Nile tilapia (Oreochromis niloticus). Aquaculture 2019, 498, 371-379. [CrossRef]

53. Hasan, M.T.; Jang, W.J.; Lee, B.J.; Kim, K.W.; Hur, S.W.; Lim, S.G.; Bai, S.C.; Kong, I.S. Heat-killed Bacillus sp. SJ-10 probiotic acts as a growth and humoral innate immunity response enhancer in olive flounder (Paralichthys olivaceus). Fish Shellfish Immunol. 2019, 88, 424-431. [CrossRef]

54. Jurado, J.; Villasanta-González, A.; Tapia-Paniagua, S.T.; Balebona, M.C.; de la Banda, I.G.; Moríñigo, M.Á.; Prieto-Álamo, M.J. Dietary administration of the probiotic Shewanella putrefaciens Pdp11 promotes transcriptional changes of genes involved in growth and immunity in Solea senegalensis larvae. Fish Shellfish Immunol. 2018, 77, 350-363. [CrossRef]

55. Chen, Z.; Ceballos-Francisco, D.; Guardiola, F.A.; Esteban, M.Á. Influence of skin wounds on the intestinal inflammatory response and barrier function: Protective role of dietary Shewanella putrefaciens SpPdp11 administration to gilthead seabream (Sparus aurata L.). Fish Shellfish Immunol. 2020, 99, 414-423. [CrossRef] [PubMed]

56. Tan, H.Y.; Chen, S.W.; Hu, S.Y. Improvements in the growth performance, immunity, disease resistance, and gut microbiota by the probiotic Rummeliibacillus stabekisii in Nile tilapia (Oreochromis niloticus). Fish Shellfish Immunol. 2019, 92, 265-275. [CrossRef] [PubMed]

57. Bano, N.; DeRae Smith, A.; Bennett, W.; Vasquez, L.; Hollibaugh, J.T. Dominance of Mycoplasma in the guts of the Long-Jawed Mudsucker, Gillichthys mirabilis, from five California salt marshes. Environ. Microb. 2007, 9, 2636-2641. [CrossRef] [PubMed]

58. Yúfera, M.; Darías, M.J. Changes in the gastrointestinal pH from larvae to adult in Senegal sole (Solea senegalensis). Aquaculture 2007, 267, 94-99. [CrossRef]

59. Cicala, F.; Lago-Lestón, A.; Gomez-Gil, B.; Gollas-Galván, T.; Chong-Robles, J.; Cortés-Jacinto, E.; Martínez-Porchas, M. Gut microbiota shifts in the giant tiger shrimp, Penaeus monodon, during the postlarvae, juvenile, and adult stages. Aquac. Int. 2020, 1-13. [CrossRef]

60. Fidopiastis, M.; Bezdek, D.J.; Horn, M.H.; Kandel, J.S. Characterizing the resident, fermentative microbial consortium in the hindgut of the temperate-zone herbivorous fish, Hermosilla azurea (Teleostei: Kyphosidae). Mar. Biol. 2006, 148, 631-642. [CrossRef]

61. Tran, N.T.; Xiong, F.; Hao, Y.T.; Zhang, J.; Wu, S.G.; Wang, G.T. Two biomass preparation methods provide insights into studying microbial communities of intestinal mucosa in grass carp (Ctenopharyngodon idellus). Aquac. Res. 2017, 48, 4272-4283. [CrossRef]

62. Wang, J.; Wang, Y.; Zhang, X.; Liu, J.; Zhang, Q.; Zhao, Y.; Peng, J.; Feng, Q.; Dai, J.; Sun, S.; et al. Gut Microbial Dysbiosis Is Associated with Altered Hepatic Functions and Serum Metabolites in Chronic Hepatitis B Patients. Front. Microbiol. 2017,8 , 2222. [CrossRef]

63. Zhang, J.; Xiong, F.; Tang Wang, G.T.; Li, W.X.; Li, M.; Zou, H.; Wu, S.G. The influence of diet on the grass carp intestinal microbiota and bile acids. Aquac. Res. 2017, 48, 4934-4944. [CrossRef]

64. Watanabe, M.; Houten, S.M.; Wang, L.; Moschetta, A.; Mangelsdorf, D.J.; Heyman, R.A.; Moore, D.D.; Auwerx, J. Bile acids lower triglyceride levels via a pathway involving FXR, SHP, and SREBP-1c. J. Clin. Investig. 2004, 113, 1408-1418. [CrossRef]

65. Givens, C.E.; Ransom, B.; Bano, N.; Hollibaugh, J.T. Comparison of the gut microbiomes of 12 bony fish and 3 shark species. Mar. Ecol. Prog. Ser. 2015, 518, 209-223. [CrossRef]

66. Corrigan, A.; de Leeuw, M.; Penaud-Frézet, S.; Dimova, D.; Murphy, R.A. Phylogenetic and functional alterations in bacterial community compositions in broiler ceca as a result of mannan oligosaccharide supplementation. Appl. Environ. Microbiol. 2015, 81, 3460-3470. [CrossRef] [PubMed]

67. Polakof, S.; Panserat, S.; Soengas, J.L.; Moon, T.W. Glucose metabolism in fish: A review. J. Comp. Physiol. B 2012, 182, 1015-1045. [CrossRef] [PubMed]

68. Conde-Sieira, M.; Salas-Leiton, E.; Duarte, M.; Pelusio, N.; Soengas, J.; Valente, L. Short- and long-term metabolic responses to diets with different protein:carbohydrate ratios in Senegalese sole (Solea senegalensis, Kaup 1858). Br. J. Nut. 2016, 115, 1896-1910. [CrossRef] [PubMed]

69. Egerton, S.; Culloty, S.; Whooley, J.; Stanton, C.; Ross, R.P. The gut microbiota of marine fish. Front. Microbiol. 2018,9 , 873. [CrossRef]

70. Xu, G.; Xing, W.; Li, T.; Xue, M.; Ma, Z.; Jiang, N.; Luo, L. Comparative study on the effects of different feeding habits and diets on intestinal microbiota in Acipenser baeri Brandt and Huso huso. BMC Microbiol. 2019, 19, 297. [CrossRef]

71. Wang, A.R.; Ran, C.; Ringø, E.; Zhou, Z.G. Progress in fish gastrointestinal microbiota research. Rev. Aquac. 2018, 10, 626-640. [CrossRef]

72. Butt, R.L.; Volkoff, H. Gut microbiota and energy homeostasis in fish. Front. Endocrinol. 2019, 10, 9. [CrossRef]

73. Basu, N.; Todgham, A.E.; Ackerman, P.A.; Bibeau, M.R.; Nakano, K.; Schulte, P.M.; Iwama, G.K. Heat shock protein genes and their functional significance in fish. Gene 2002, 295, 173-183. [CrossRef]

74. Huo, D.; Sun, L.; Zhang, L.; Yang, H.; Liu, S.; Sun, J.; Su, F. Time course analysis of immunity-related gene expression in the sea cucumber Apostichopus japonicus during exposure to thermal and hypoxic stress. Fish Shellfish Immunol. 2019, 95, 383-390. [CrossRef]

75. Chen, Y.M.; Kuo, C.E.; Wang, T.Y.; Shie, P.S.; Wang, W.C.; Huang, S.L.; Chen, T.Y. Cloning of an orange-spotted grouper Epinephelus coioides heat shock protein 90AB (HSP90AB) and characterization of its expression in response to nodavirus. Fish Shellfish Immunol. 2010, 28, 895-904. [CrossRef] [PubMed] 
76. Schild, H.; Rammensee, H.G. gp96-the immune system's Swiss army knife. Nat. Immunol. 2000, 1, 100-101. [CrossRef]

77. Núñez-Díaz, J.A.; Fumanal, M.; Mancera, J.M.; Moriñigo, M.A.; Balebona, M.C. Two routes of infection with Photobacterium damselae subsp. piscicida are effective in the modulation of the transcription of immune related genes in Solea senegalensis. Vet. Immunol. Immunopathol. 2016, 179, 8-17. [CrossRef]

78. Trusch, F.; Loebach, L.; Wawra, S.; Durward, E.; Wuensch, A.; Iberahim, N.A.; de Bruijn, I.; MacKenzie, K.; Willems, A.; Toloczko, A.; et al. Cell entry of a host-targeting protein of oomycetes requires gp96. Nat. Commun. 2018, 9, 1-12. [CrossRef]

79. Cara, J.B.; Aluru, N.; Moyano, F.J.; Vijayan, M.M. Food-deprivation induces HSP70 and HSP90 protein expression in larval gilthead sea bream and rainbow trout. Comp. Biochem. Physiol. B. Biochem. Mol. Biol. 2005, 142, 426-431. [CrossRef] [PubMed]

80. Wei, X.; Li, B.; Wu, L.; Yin, X.; Zhong, X.; Li, Y.; Ye, J. Interleukin-6 gets involved in response to bacterial infection and promotes antibody production in Nile tilapia (Oreochromis niloticus). Dev. Comp. Immunol. 2018, 89, 141-151. [CrossRef]

81. Bird, S.; Zou, J.; Savan, R.; Kono, T.; Sakai, M.; Woo, J.; Secombes, C. Characterisation and expression analysis of an interleukin 6 homologue in the Japanese pufferfish, Fugu rubripes. Dev. Comp. Immunol. 2005, 29, 775-789. [CrossRef]

82. Panigrahi, A.; Kiron, V.; Satoh, S.; Hirono, I.; Kobayashi, T.; Sugita, H.; Puangkaew, J.; Aoki, T. Immune modulation and expression of cytokine genes in rainbow trout Oncorhynchus mykiss upon probiotic feeding. Dev. Comp. Immunol. 2007, 31, 372-382. [CrossRef] [PubMed]

83. Caipang, C.M.A.; Hynes, N.; Puangkaew, J.; Brinchmann, M.F.; Kiron, V. Intraperitoneal vaccination of Atlantic cod, Gadus morhua with heat-killed Listonella anguillarum enhances serum antibacterial activity and expression of immune response genes. Fish Shellfish Immunol. 2008, 24, 314-322. [CrossRef] [PubMed]

84. Yan, Y.Y.; Xia, H.Q.; Yang, H.L.; Hoseinifar, S.H.; Sun, Y.Z. Effects of dietary live or heat-inactivated autochthonous Bacillus pumilus SE 5 on growth performance, immune responses and immune gene expression in grouper Epinephelus coioides. Aquac. Nutr. 2016, 22, 698-707. [CrossRef]

85. Sun, Z.; Tan, X.; Ye, H.; Zou, C.; Ye, C.; Wang, A. Effects of dietary Panax notoginseng extract on growth performance, fish composition, immune responses, intestinal histology and immune related genes expression of hybrid grouper (Epinephelus lanceolatus $\times$ Epinephelus fuscoguttatus) fed high lipid diets. Fish Shellfish Immunol. 2018, 73, 234-244. [CrossRef]

86. Holland, M.C.H.; Lambris, J.D. The complement system in teleosts. Fish Shellfish Immunol. 2002, 12, 399-420. [CrossRef]

87. Li, H.; Zhou, Y.; Ling, H.; Luo, L.; Qi, D.; Feng, L. The effect of dietary supplementation with Clostridium butyricum on the growth performance, immunity, intestinal microbiota and disease resistance of tilapia (Oreochromis niloticus). PLoS ONE 2019, 14, e223428. [CrossRef] [PubMed]

88. Rebl, A.; Goldammer, T. Under control: The innate immunity of fish from the inhibitors' perspective. Fish Shellfish Immunol. 2018, 77, 328-349. [CrossRef] [PubMed]

89. Ragland, S.A.; Criss, A.K. From bacterial killing to immune modulation: Recent insights into the functions of lysozyme. PLoS Pathog. 2017, 13, e1006512. [CrossRef] [PubMed]

90. Dawood, M.A.; Koshio, S.; Abdel-Daim, M.M.; Van Doan, H. Probiotic application for sustainable aquaculture. Rev. Aquac. 2019, 11, 907-924. [CrossRef]

91. Liu, B.; Xu, L.; Ge, X.; Xie, J.; Xu, P.; Shou, Q.; Pan, L.; Zhang, Y. Effects of mannan oligosaccharide on the physiological responses, HSP70 gene expression and disease resistance of Allogynogenetic crucian carp (Carassius auratus gibelio) under Aeromonas hydrophila infection. Fish Shellfish Immunol. 2013, 34, 1395-1403. [CrossRef] [PubMed]

92. Haase, M.; Fitze, G. HSP90AB1: Helping the good and the bad. Gene 2016, 575, 171-186. [CrossRef]

93. Sung, Y.Y.; MacRae, T.H. Heat Shock Proteins and disease control in aquatic organisms. J. Aquac. Res. Dev. 2011, 3, 1-10. [CrossRef]

94. Zeng, F.; Tee, C.; Liu, M.; Sherry, V.; Dixon, B.; Duncker, B.P.; Bols, N.C. The p53/ HSP70 inhibitor, 2-phenylethynesulfonamide, causes oxidative stress, unfolded protein response and apoptosis in rainbow trout cells. Aquat. Toxicol. 2014, 146, 45-51. [CrossRef]

95. Núñez-Díaz, J.A.; de la Banda, I.G.; Lobo, C.; Moriñigo, M.A.; Balebona, M.C. Transcription of immune related genes in Solea senegalensis vaccinated against Photobacterium damselae subsp. piscicida. Identification of surrogates of protection. Fish Shellfish Immunol. 2017, 66, 455-465. [CrossRef] [PubMed]

96. Jiang, J.; Shi, D.; Zhou, X.Q.; Yin, L.; Feng, L.; Jiang, W.D.; Liu, Y.; Tang, L.; Wu, P.; Zhao, Y. Vitamin D inhibits lipopolysaccharideinduced inflammatory response potentially through the Toll-like receptor 4 signaling pathway in the intestine and enterocytes of juvenile jian carp (Cyprinus carpio var. jian). Br. J. Nutr. 2015, 114, 1560-1568. [CrossRef]

97. Bo, Y.X.; Song, X.H.; Wu, K.; Hy, B.; Sun, B.Y.; Liu, Z.J.; Fu, J.G. Characterization of interleukin-1beta as a proinflammatory cytokine in grass carp (Ctenopharyngodon idella). Fish Shellfish Immunol. 2015, 46, 584-595. [CrossRef]

98. Burrello, C.; Garavaglia, F.; Cribiù, F.M.; Ercoli, G.; Bosari, S.I.; Caprioli, F.; Facciotti, F. Short-term oral antibiotics treatment promotes inflammatory activation of colonic invariant natural killer T and conventional CD4 ${ }^{+}$T cells. Front. Med. 2018, 5-21. [CrossRef] [PubMed]

99. Nayak, S.K.; Nakanishi, T. Direct antibacterial activity of CD8 ${ }^{+} / \mathrm{CD} 4^{+}$T-cells in ginbuna crucian carp, Carassius auratus langsdorfii. Fish Shellfish Immunol. 2013, 34, 136-141. [CrossRef] [PubMed] 